\title{
Parity Reversion in Real Exchange Rates: Fast, Slow, or Not at All?
}

\author{
PAUL CASHIN AND C. JOHN MCDERMOTT*
}

This paper tests for purchasing power parity (PPP) using real effective exchange rate data for 90 developed and developing countries in the post-Bretton Woods period. Support for PPP is found, since the majority of countries experience finite deviations of real exchange rates from parity. The speed of parity reversion is found to be typically much faster for developed countries than for developing countries and to be considerably faster for countries with flexible nominal exchange rate regimes compared with countries having fixed nominal exchange rate regimes. [JEL C22, F31, F41]

\section{$\mathrm{E}$} xchange rates have been at the center of policy and academic debates in developing and developed countries, especially since the floating of developedcountry exchange rates in the early 1970 s, which marked the commencement of the post-Bretton Woods period. Despite these debates, several key empirical questions regarding the stylized facts of exchange rates remain largely unresolved, particularly in the little-researched area of real exchange rate behavior in developing countries (Edwards and Savastano, 2000). Several of these exchange rate-related questions are tackled in this paper: Do real exchange rates really display parity-reverting behavior? Is purchasing power parity (PPP) an appropriate (very) long-run benchmark for

*Paul Cashin is Deputy Division Chief in the Caribbean I Division of the IMF's Western Hemisphere Department; John McDermott is Associate Professor, School of Economics and Finance, Victoria University, New Zealand. The authors thank Robert Flood, Sam Ouliaris, Christopher Plantier, Carmen Reinhart, Kenneth Rogoff, Lauren Rosborough, Lucio Sarno, Miguel Savastano, Mark Taylor, and seminar participants at the 12th Meeting of the New Zealand Econometrics Study Group and the International Monetary Fund for helpful comments and suggestions on earlier versions of the paper, and Chi Nguyen and Manzoor Gill for excellent research assistance. 
assessing real exchange rate developments? Does the behavior of real exchange rates differ among developed and developing countries? Are there important differences in the extent of parity reversion when comparing countries with fixed nominal exchange rate regimes and those with flexible nominal exchange rate regimes? Can we explain cross-country heterogeneity of parity reversion using countries' structural characteristics, and, if so, which characteristics appear to be important? In this study we examine the empirical support for PPP through timeseries analysis of the persistence of shocks to the real effective exchange rates of 90 developed and developing countries in the post-Bretton Woods period.

The theory of PPP, in its most rudimentary form, states that there is an equilibrium level to which exchange rates converge, so that foreign currencies should have the same purchasing power. ${ }^{1}$ Therefore, long-run PPP is inconsistent with a unit root in real exchange rates. The reason for this is that a shock to a unit root process will have permanent effects on all future values of the series, potentially without bound. ${ }^{2}$ Unfortunately, formal statistical tests that compare the unit root (UR) model against the alternative of a stationary autoregressive (AR) model typically lead to a failure to reject the hypothesis of a unit root.

There are a number of econometric problems with using the UR/AR model to test for PPP. First, least squares estimators of AR models bias empirical results in favor of finding PPP. This downward bias becomes particularly acute when the AR parameter is close to unity. As lower values of the AR parameter imply faster speeds of adjustment following a shock, this will also result in a downward bias to estimates of half-lives of shocks. This near unit root bias is likely to be particularly relevant for real exchange rates, as they are often found to be stationary yet exhibit shocks that are highly persistent. Second, unit root tests tend to be uninformative regarding the speed of parity reversion, because a rejection of the unit root null could still be consistent with a stationary model of real exchange rates that has highly persistent shocks. This leads to problems about how to interpret results and often yields arbitrary conclusions that are dependent on the predisposition of the researcher.

This paper makes several contributions to the literature. First, it reports medianunbiased estimates of the half-lives of real exchange rate adjustment for 90 developed and developing countries over the post-Bretton Woods period. To the best of our knowledge, this study is the first to apply median-unbiased estimation methods to developing-country real exchange rate data. ${ }^{3}$ Second, we use Andrews' (1993) unbiased model-selection rule to draw conclusions as to the presence (or absence) of parity reversion of real exchange rates in the post-Bretton Woods period. In particular, finite half-lives constructed from bias-corrected estimation indicate that

\footnotetext{
${ }^{1}$ Since the present study of PPP employs data on price indices rather than price levels, we are examining the relevance of relative PPP: the notion that the percentage change in the nominal effective exchange rate should compensate for the inflation differential between the home country and a weighted average of partner countries. This test of relative PPP is more stringent than the usual test, which uses first differences of the real exchange rate.

${ }^{2}$ For surveys on PPP and exchange rate economics, see Froot and Rogoff (1995), Sarno and Taylor (2002), and Taylor (2003).

${ }^{3}$ Recent work on testing PPP and the stationarity of real exchange rates in developing countries includes Bahmani-Oskooee (1995) and Montiel (1997), among others; studies concentrating on Latin American countries include Devereux and Connolly (1996) and Calvo, Reinhart, and Végh (1995).
} 
real exchange rate shocks are mean-reverting. Third, we break down the half-lives estimated by geographic region, income level, dominant exportable, and exchange rate regime. Fourth, we attempt to explain the heterogeneity in the duration of parity reversion by examining bivariate correlations between estimated half-lives and potential nominal factors (inflation and choice of nominal exchange rate regime) and potential real factors (trade openness, productivity growth, and government spending). Finally, this study extends Cashin and McDermott (2003) by covering a larger sample of country real exchange rates for the post-Bretton Woods period, and attempting to explain the factors driving the observed heterogeneity of the duration of exchange rate deviations from parity.

We have several key findings. First, using post-Bretton Woods data on the real effective exchange rates of 90 industrial and developing countries and least squares estimation of unit root models, we replicate Rogoff's (1996) consensus estimate of the half-life of deviations from PPP of three to five years. Second, using medianunbiased estimates, we find that for 40 countries in our sample, deviations of the real exchange rate from parity are best viewed as being permanent. However, the majority (50) of the countries have finite half-life estimates - this evidence of real exchange rate reversion to parity is consistent with PPP holding in the post-Bretton Woods period. Third, the median half-life of parity deviations for industrial countries (eight years) is much shorter than that for developing countries (permanent). Fourth, the median half-life of parity deviation for countries with fixed nominal exchange rate regimes (permanent) is considerably longer than that for countries with flexible nominal exchange rate regimes (six years). Fifth, two key structural characteristics that affect the persistence of shocks to real exchange rates are differences in a country's inflation experience and the extent of nominal exchange rate volatility. Finally, the existing literature on measuring parity reversion in developing countries has largely concentrated on the Latin America experience (which is dominated by high-inflation countries). This sample-selection bias has resulted in the erroneous finding that parity reversion in developing countries is faster than that observed in developed countries.

\section{Measures of Speed of Parity Reversion}

The presence of unit roots in real exchange rates is incompatible with long-run PPP. Consequently, unit root tests that focus on whether shocks are mean-reverting or not have been widely used to test for long-run PPP. However, it is preferable to use measures of the speed of reversion in evaluating PPP, because a very persistent real exchange rate can still be incompatible with how PPP is interpreted in theories of exchange rate determination. Conversely, failure to reject a unit root test may occur as a result of the well-known low power properties of unit root tests, when in fact PPP may hold in longer-term data. As a consequence, recent papers examining the persistence of exchange rate shocks in the post-Bretton Woods period have used estimates of the half-life of parity deviations (Andrews, 1993; Andrews and Chen, 1994; and Cheung and Lai, 2000b). ${ }^{4}$

\footnotetext{
${ }^{4}$ Biased and bias-corrected point estimates of the half-life of shocks to economic time series have also been used by Cashin, Liang, and McDermott (2000) in modeling the persistence of shocks to world
} 
We use the $\operatorname{AR}(p)$ model to measure the degree of persistence in real exchange rates. The $\operatorname{AR}(p)$ model (also known as an Augmented Dickey-Fuller, or ADF, regression) takes the form

$$
q_{t}=\mu+\alpha q_{t-1}+\sum_{i=1}^{p-1} \psi_{i} \Delta q_{t-1}+\varepsilon_{t} \quad \text { for } t=1, \ldots, T,
$$

where the observed real exchange rate series is $q_{t}: t=-p, \ldots, T, \mu$ the intercept, $\alpha$ the autoregressive parameter (where $\alpha \in(-1,1]$ ), and $\varepsilon_{t}$ are the innovations of the model. The lagged first differences are included to control for the presence of serial correlation. The $\alpha$ parameter in equation (1) can be corrected for the downward bias present in such regression by using the methods suggested by Andrews and Chen (1994). ${ }^{5}$ The bias correction delivers an impartiality property to the decisionmaking process, because there is an equal chance of under- or overestimating the AR parameter. Moreover, an unbiased estimate of $\alpha$ will allow us to calculate an unbiased scalar estimate of persistence-the half-life of a unit shock.

\section{Model Selection Rule}

Testing the PPP proposition is a controversial subject that has not yet been resolved. Most modern time-series tests of PPP are based on testing whether $\alpha<1$ in AR models of the real exchange rate, as in equation (1). Unit root tests based on classical hypothesis tests tend to have a null hypothesis where PPP does not holdthat is, the null hypothesis is that PPP deviations are permanent. Further, because of the low power properties of these tests (at least against reasonable alternatives), the tests often fail to reject the null. In particular, slow (albeit positive) reversion of real exchange rates toward PPP yields unit root tests that provide little information against relevant alternative hypotheses (Froot and Rogoff, 1995). The typically large estimated confidence intervals around the point estimate of $\alpha$ make it clear that the level of uncertainty about the value of the "true" $\alpha$ is very high. Nevertheless, practitioners often use hypothesis tests as a formal model-selection rule.

Andrews (1993) offers a solution to this impasse by introducing a statistical procedure whereby the probability of selecting the "true" model is at least as large as the probability of selecting the false model. Unbiased model-selection procedures have an impartiality property that may be useful if the selection of one model or another (such as the trend stationary or unit root model) is a contentious issue. In essence, the issue is to select one of two models defined by $\alpha \in I_{a}$ and $\alpha \in I_{b}$, where $I_{a}$ and $I_{b}$ are intervals partitioning the parameter space $(-1,1]$ for $\alpha$, with $I_{a}=(-1,1)$ and $I_{b}=\{1\}$ (Andrews, 1993, p. 152).

commodity prices; by McDermott (1996), Murray and Papell (2002), and Cashin and McDermott (2003) in modeling the persistence of parity deviations in developed-country real exchange rates; and by Cashin, McDermott, and Pattillo (2004) in examining the persistence of terms of trade shocks.

${ }^{5}$ See Cashin and McDermott (2003) for details on the downward bias of autoregressive parameters derived from least squares estimates of AR models and Andrews' (1993) method for bias-correcting the least squares estimator. 


\section{Calculating Half-Lives}

The main objective of using the autoregressive model is to extract the degree of persistence inherent in real exchange rates. Specifically, we use the half-life of shocks implied by such models to measure persistence. The half-life is defined as the duration of time it takes for a unit impulse to dissipate permanently by one half from the occurrence of the initial shock (Cheung and Lai, 2000b). That is, the halflife (denoted by $l_{h}$ ) is given by $\operatorname{IR}\left(l_{h}\right) \leq 1 / 2$ such that $l_{h+k}<1 / 2$ for $k=1,2, \ldots$, where the impulse-response function is given by $\operatorname{IR}(h)=f_{11}(h)$ for $h=0,1,2, \ldots$, and $f_{11}(h)$ denotes the $(1,1)$ element of $F^{h}$, where $F$ is the $(p \times p)$ matrix

$$
F \equiv\left[\begin{array}{cccccc}
\alpha+\psi_{1} & \psi_{2}-\psi_{1} & \psi_{3}-\psi_{2} & \cdots & \psi_{p-1}-\psi_{p-2} & -\psi_{p-1} \\
1 & 0 & 0 & \cdots & 0 & 0 \\
0 & 1 & & \cdots & 0 & 0 \\
\vdots & \vdots & \vdots & \ddots & \vdots & \vdots \\
0 & 0 & 0 & \cdots & 0 & 0 \\
0 & 0 & 0 & \cdots & 1 & 0
\end{array}\right]
$$

and

$$
\alpha_{i} \equiv\left\{\begin{array}{lc}
\alpha+\psi_{1} & i=1, \\
\psi_{i}-\psi_{i-1} & i=2, \ldots, p-1, \\
-\psi_{p-1} & i=p .
\end{array}\right.
$$

We could also construct two-sided 90 percent (or one-sided 95 percent) confidence intervals for the half-life estimates, as in Cashin, Liang, and McDermott (2000); Cheung and Lai (2000b); and Murray and Papell (2002). Because such intervals are typically very wide, the null hypothesis that the half-life is permanent is rarely rejected. Such a finding leaves us in the awkward position of having to provisionally accept that PPP does not hold or resigning ourselves to the fact that we cannot make a decision at all because the degree of uncertainty attached to the estimate of the half-life is too high. Murray and Papell (2002) favor the latter option.

However, empirical researchers will typically (for better or worse) make a judgment as to whether the model is acceptable or not. Failure to reject the null of a unit root often invokes the argument that the test was not powerful enough, and researchers then proceed as if the null is false. This approach seems unsatisfactory and is one that will often deliver different conclusions from different researchers, because each is now using an arbitrary decision rule-an undisclosed and implicit decision rule at that. Instead, a more natural procedure is to use the unbiased model-selection rule of Andrews (1993), which offers an objective means to determine which model best represents the data. Moreover, because the rule is clear and explicit, different researchers can use it to verify results in an objective manner. Use of Andrews' (1993) unbiased model-selection rule and median-unbiased estimation 
means that we have used a 0.5 (unbiased) test of the null hypothesis of a finite half-life versus the alternative hypothesis of a permanent half-life (see Cashin and McDermott, 2003).

There are other methods we could have used to examine the cross-country experiences of the persistence of parity deviations. One approach is to use long-span time series to analyze the persistence of real exchange rates. However, this approach is clouded by the differing nominal exchange rate regimes used by any given country over time. In order to provide a useful test of the validity of the notion of purchasing power parity in the post-Bretton Woods period, a test needs to be derived using data specifically from that period. Another approach would be to use multivariate generalizations of unit root tests of the real exchange rate (through panel unit root analyses of long-run PPP). This approach also has substantial problems. In particular, the use of panel unit root tests has been criticized because authors have typically presumed that rejection of the joint null hypothesis of unit root (nonreversion) behavior of the whole panel of real exchange rates implies that all real exchange rates are stationary. In actuality, rejection of the null only implies that at least one of the real exchange rates is stationary (or mean-reverting). A third approach would be to use nonlinear methods, as Taylor and Sarno (1998) do. In some sense, this approach complements the approach used in this paper.

\section{Data}

In this and the following section, we will investigate the properties of real exchange rate persistence. The data used to estimate the near unit root model are monthly time series of the real exchange rate obtained from the International Monetary Fund's International Financial Statistics (IFS) from the third quarter of 1973 to the third quarter of 2002 (the post-Bretton Woods period), which gives a total of 348 observations (see Appendix I for additional details). Appendix I also lists the derivation and description of the variables used in Section IV to explain the crosscountry heterogeneity of the duration of real exchange rate shocks. The definition of the real exchange rate is the real effective exchange rate (REER) based on consumer prices (line rec), for which 20 industrial and 70 developing countries were selected. 6

The REER data for six representative countries are set out in Figure 1-an increase in the REER series indicates a real appreciation of the country's currency. ${ }^{7}$ The data reveal that most countries have real exchange rates that exhibit drift or nonstationarity - that is, there are periods of sustained deviation from PPP. The evolution of REER appears to be a highly persistent process; for most countries, the REER does not appear to converge to any particular equilibrium value, with the possible exception of Sweden. Also, sharp movements in the REER during the

\footnotetext{
${ }^{6}$ For a detailed explanation and critique of how the Fund's REER indices are constructed, see Wickham (1993) and Zanello and Desruelle (1997).

${ }^{7}$ The 20 industrial countries and 70 developing countries are listed in Table 1 . A decline (depreciation) in a country's REER index indicates a rise in its international competitiveness (defined as the relative price of domestic tradable goods in terms of foreign tradables).
} 
Figure 1. Real Effective Exchange Rate, Selected Countries, $1973: 3-2002: 3(1990=100)$

Sweden

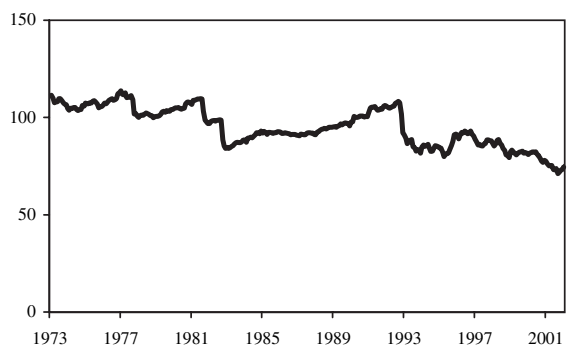

United States

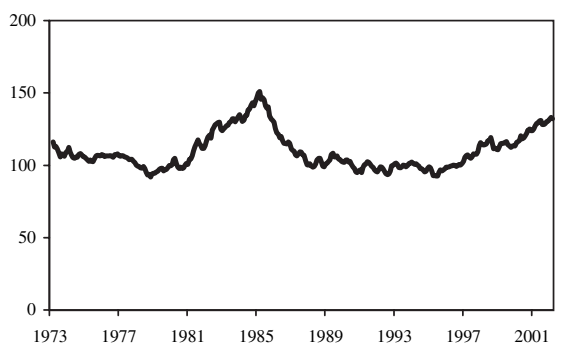

United Kingdom

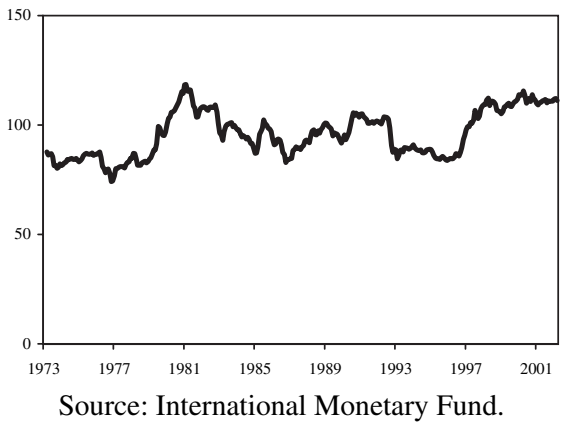

Indonesia

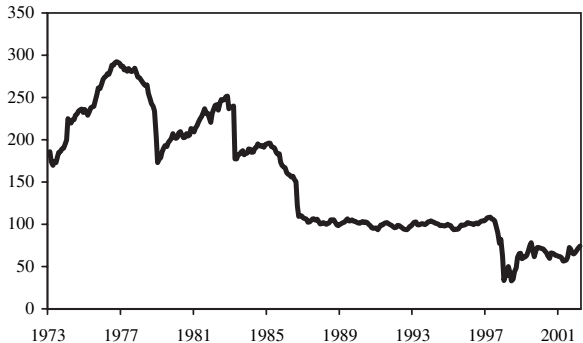

Nigeria

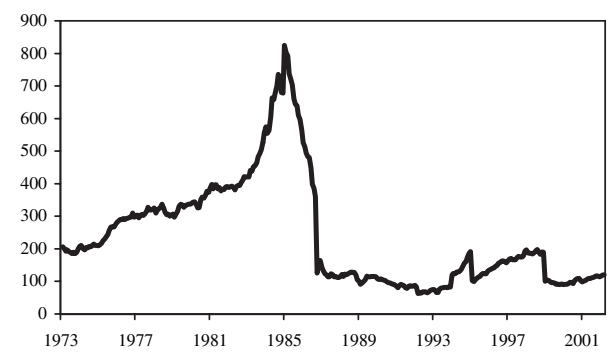

Mexico

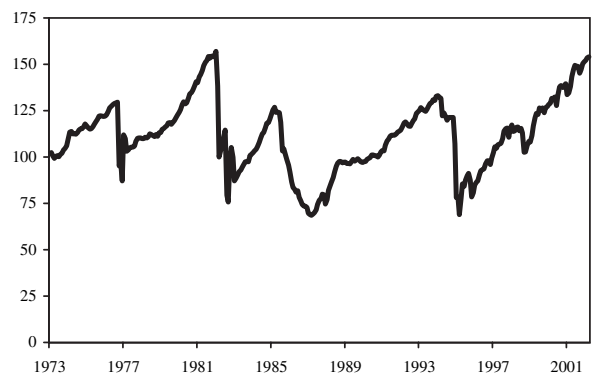

1980s and 1990s are a relatively frequent occurrence, especially for developing countries, such as Indonesia, Nigeria, and Mexico.

\section{Empirical Results}

In this section, we present our estimates of the persistence of parity deviations. We then examine the cross-country heterogeneity of the persistence results by grouping the countries using several key characteristics, such as income level, type of nominal exchange rate regime, type of dominant exportable, and geographic location. 


\section{Biased Least Squares Estimates of Half-Lives of Parity Reversion}

The results for the half-life of the duration of shocks to the REER, calculated from the least squares estimates of $\alpha$ in ADF regression of equation (1), are set out in Table 1. Across all countries, the average (median) half-life of parity reversion is 4.04 years. This result is consistent with Rogoff's (1996) consensus of half-lives of parity reversion of between 36 and 60 months (three to five years), and with Cheung and Lai's (2000b) finding of median half-lives of 3.3 years for industrial countries in the post-Bretton Woods period.

\section{Median-Unbiased Estimates of Half-Lives of Parity Reversion}

The half-lives of PPP deviations calculated above (using the least squares estimator) are reasonably close to past studies but are likely to be biased downward and in favor of finding that PPP holds in the REER data. Consequently, we remove this bias by calculating median-unbiased estimates for the autoregressive parameter in equation (1).

The median-unbiased estimates of half-lives derived from the AR parameter in $\mathrm{ADF}$ regressions are reported in Table 1. In comparison with their least squares counterparts, they are typically much longer, ranging from as little as one month (Bolivia) to infinity (Belgium and Sweden, among others). Across all countries, the average (median) half-life of parity reversion is 8.17 years, in excess of the average least squares $\operatorname{AR}(p)$ half-life of 4.04 years. ${ }^{8}$ This implies a rate of parity reversion of only 8 percent a year, rather than the 16 percent a year calculated using least squares.

Using the Andrews unbiased model-selection rule, we find that 50 of the countries are subject to finitely persistent shocks to their REER (which is consistent with the reversion of REER to parity), whereas 40 of the countries experience permanent shocks to their REER series. The interpretation of this rule is that for any given country, there is a 50 percent probability that the interval from zero to the estimated median-unbiased half-life contains the true half-life. There is also a 50 percent probability that the interval from the estimated median-unbiased half-life to infinity contains the true half-life. Let us take the examples of Iceland (short-lived half-life) and Togo (infinite half-life). For Iceland, while there is a 50 percent probability that the interval from zero to 1.1 years contains the true half-life, there is also a 50 percent probability that the interval from 1.1 years to infinity contains the true half-life. For Togo, while there is a 50 percent probability that the interval with a finite upper bound contains the true half-life, there is a 50 percent probability that the true half-life will be infinite (Table 1). Using the Andrews (1993) unbiased model-selection rule, the finite (Iceland) and infinite (Togo) estimates of the half-lives indicate that while shocks to Iceland's REER are transitory, shocks to Togo's REER are best viewed as being permanent.

\footnotetext{
8In calculating group and all-country median half-lives of deviation from parity, a permanent deviation is defined as one that is at least as long as the span of the data. In our sample, the data span 29 years, so permanent deviation from parity (infinite shock) is set to equal 30 years.
} 


\section{Table 1. Half-Lives of Reversion to Parity (years), Real Effective Exchange Rates, March 1973-March 2002, Advanced and Developing Countries}

$\begin{array}{lcccc} & \text { Biased } & \text { Unbiased } & \text { Time to } & \text { Time to } \\ \text { Country } & \text { Half-Life } & \text { Half-Life } & \text { Peak } & \text { Unity } \\ (1) & (2) & (3) & (4) & (5)\end{array}$

\section{Belgium}

Sweden

Portugal

Austria

Italy

Spain

Australia

Canada

Japan

United States

Ireland

Finland

Germany

Netherlands

United Kingdom

Korea, Rep. of

Switzerland

Norway

New Zealand

Iceland

Advanced countries median

Burkina Faso

Chad

Central African Republic

Gabon

Lesotho

Madagascar

Mauritania

Mauritius

Morocco

Senegal

Togo

Tunisia

Niger

Gambia, The

Ethiopia

Tanzania

Cameroon

Seychelles

Nigeria

Congo, Rep. of

Kenya

Sierra Leone

\section{ADVANCED COUNTRIES}

\subsection{0}

5.83

4.92

3.92

3.67

3.58

3.67

5.42

5.00

4.25

2.75

3.75

3.25

3.42

3.25

2.08

1.75

1.83

1.75

1.00

3.63

\section{AFRICA}

10.92

11.75

14.17

$\infty$

8.33

$\infty$

4.17

9.67

8.17

6.42

10.67

$\infty$

1.17

4.83

6.33

3.08

2.67

4.25

1.42

2.00

1.00 $\infty$

$\infty$

8.42

8.25

8.17

8.17

8.00

8.00

8.00

7.83

7.50

5.50

5.50

5.50

5.42

3.17

2.67

2.50

1.83

1.08

7.67

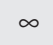

$\infty$

$\infty$

$\infty$

$\infty$

$\infty$

$\infty$

$\infty$

$\infty$

$\infty$

$\infty$

$\infty$

$\infty$

$\infty$

$\infty$

14.17

7.25

6.83

5.58

4.83

4.33

4.33

\subsection{0}

0.33

0.92

0.83

1.00

0.75

0.08

1.25

1.00

1.00

0.25

1.33

0.83

0.83

0.33

0.17

0.08

0.08

0.08

0.08

0.79

0.08

17.58

0.08

3.67

1.42

0.17

0.33

0.17

0.17

0.50

0.08

2.08

0.08

0.25

0.83

1.17

0.25

0.17

1.50

0.08

0.08

0.08

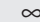

$\infty$

3.17

3.25

3.17

3.25

0.67

4.50

4.17

4.58

0.83

3.50

2.50

2.58

2.25

0.83

0.92

0.33

0.92

0.08

$\mathrm{NCU}$

$\infty$

$\mathrm{NCU}$

$\infty$

$\infty$

$\mathrm{NCU}$

$\mathrm{NCU}$

NS

NS

$\mathrm{NCU}$

$\mathrm{NCU}$

$\infty$

$\mathrm{NCU}$

$\mathrm{NCU}$

$\infty$

8.42

S

0.25

3.83

$\mathrm{S}$

0.25

0.25 


\begin{tabular}{|c|c|c|c|c|}
\hline \multicolumn{5}{|c|}{ Table 1 (continued) } \\
\hline $\begin{array}{l}\text { Country } \\
\text { (1) }\end{array}$ & $\begin{array}{c}\text { Biased } \\
\text { Half-Life } \\
\text { (2) }\end{array}$ & $\begin{array}{l}\text { Unbiased } \\
\text { Half-Life } \\
\text { (3) }\end{array}$ & $\begin{array}{l}\text { Time to } \\
\text { Peak } \\
\text { (4) }\end{array}$ & $\begin{array}{l}\text { Time to } \\
\text { Unity } \\
(5)\end{array}$ \\
\hline Côte d' Ivoire & 2.17 & 3.25 & 0.25 & $\mathrm{~S}$ \\
\hline Malawi & 2.25 & 3.17 & 0.08 & 0.75 \\
\hline Ghana & 1.75 & 2.75 & 0.08 & 0.17 \\
\hline Zambia & 0.67 & 1.50 & 0.08 & 0.08 \\
\hline Uganda & 1.00 & 1.25 & 0.08 & $\mathrm{~S}$ \\
\hline Rwanda & 0.50 & 1.17 & 0.08 & 0.17 \\
\hline Sudan & 0.92 & 1.00 & 0.33 & 0.42 \\
\hline Congo, Dem. Rep. of & 0.42 & 0.42 & 0.08 & $\mathrm{~S}$ \\
\hline Africa median & 4.21 & 22.08 & 0.17 & \\
\hline \multicolumn{5}{|c|}{ WESTERN HEMISPHERE } \\
\hline Colombia & 8.00 & $\infty$ & 3.25 & $\infty$ \\
\hline Dominican Republic & 5.25 & $\infty$ & 0.58 & NS \\
\hline Ecuador & 6.33 & $\infty$ & 0.92 & $\infty$ \\
\hline El Salvador & $\infty$ & $\infty$ & 0.75 & $\infty$ \\
\hline Guatemala & 5.42 & $\infty$ & 0.50 & $\infty$ \\
\hline Haiti & 19.33 & $\infty$ & 0.08 & NS \\
\hline Honduras & 5.17 & $\infty$ & 0.67 & $\infty$ \\
\hline Paraguay & 4.50 & $\infty$ & 0.17 & NS \\
\hline Venezuela & 6.25 & $\infty$ & 0.17 & $\infty$ \\
\hline Panama & 10.08 & $\infty$ & 0.08 & $\mathrm{NCU}$ \\
\hline Peru & 1.00 & $\infty$ & 0.17 & 0.33 \\
\hline Guyana & 12.50 & $\infty$ & $\infty$ & $\infty$ \\
\hline Jamaica & 4.42 & 8.33 & 1.25 & 3.50 \\
\hline Trinidad and Tobago & 3.92 & 7.75 & 1.00 & 4.17 \\
\hline Uruguay & 3.25 & 7.25 & 0.08 & 0.33 \\
\hline Costa Rica & 3.08 & 3.83 & 0.83 & 1.33 \\
\hline Argentina & 2.75 & 3.58 & 0.75 & 2.08 \\
\hline Barbados & 2.58 & 3.50 & 0.17 & 0.92 \\
\hline Chile & 2.50 & 2.75 & 0.92 & 1.17 \\
\hline Brazil & 1.75 & 2.50 & 0.08 & 0.42 \\
\hline Mexico & 1.75 & 1.92 & 0.50 & 0.50 \\
\hline Bolivia & 0.08 & 0.08 & 0.08 & $\mathrm{~S}$ \\
\hline Western Hemisphere median & 4.46 & $\infty$ & 0.54 & \\
\hline \multicolumn{5}{|c|}{ ASIA, MIDDLE EAST, AND EUROPE } \\
\hline Fiji & 4.75 & $\infty$ & 0.08 & $\mathrm{NCU}$ \\
\hline Hungary & $\infty$ & $\infty$ & 1.83 & $\infty$ \\
\hline India & 17.67 & $\infty$ & 16.75 & $\infty$ \\
\hline Indonesia & 11.92 & $\infty$ & 0.75 & NS \\
\hline Malaysia & 8.25 & $\infty$ & 0.33 & $\infty$ \\
\hline Malta & 7.08 & $\infty$ & 20.00 & $\infty$ \\
\hline Myanmar & $\infty$ & $\infty$ & $\infty$ & $\infty$ \\
\hline Pakistan & $\infty$ & $\infty$ & 2.00 & $\infty$ \\
\hline Papua New Guinea & 1.83 & $\infty$ & 0.08 & $\mathrm{NCU}$ \\
\hline Thailand & 6.17 & $\infty$ & 0.17 & NS \\
\hline Nepal & 9.33 & $\infty$ & 0.17 & $\mathrm{NCU}$ \\
\hline
\end{tabular}




\begin{tabular}{|c|c|c|c|c|}
\hline \multicolumn{5}{|c|}{ Table 1 (concluded) } \\
\hline $\begin{array}{l}\text { Country } \\
\text { (1) }\end{array}$ & $\begin{array}{c}\text { Biased } \\
\text { Half-Life } \\
\quad(2)\end{array}$ & $\begin{array}{c}\text { Unbiased } \\
\text { Half-Life } \\
\text { (3) }\end{array}$ & $\begin{array}{c}\text { Time to } \\
\text { Peak } \\
\text { (4) }\end{array}$ & $\begin{array}{c}\text { Time to } \\
\text { Unity } \\
\text { (5) }\end{array}$ \\
\hline Philippines & 3.50 & 8.08 & 0.42 & 2.17 \\
\hline Syrian Arab Republic & 4.42 & 7.92 & 0.75 & 3.25 \\
\hline Samoa & 3.33 & 7.83 & 0.92 & $\mathrm{~S}$ \\
\hline Turkey & 1.92 & 5.67 & 0.08 & 0.17 \\
\hline Iran, Islamic Republic of & 3.08 & 5.42 & 0.67 & 0.92 \\
\hline Sri Lanka & 2.50 & 5.17 & 0.17 & 1.50 \\
\hline Egypt & 2.00 & 2.42 & 0.42 & 0.25 \\
\hline $\begin{array}{l}\text { Asia, Middle East, and } \\
\text { Europe median }\end{array}$ & 5.46 & $\infty$ & 0.54 & \\
\hline All countries median & 4.04 & 8.17 & 0.33 & \\
\hline \multicolumn{5}{|c|}{$\begin{array}{l}\text { Source: Authors' calculations. } \\
\text { Notes: Column (2): Biased half-life of parity deviation, based on least squares estimation of the } \\
\text { gmented Dickey-Fuller regression of equation (1). The half-life for AR }(p) \text { models is calculated } \\
\text { m the impulse-response functions (IRF) and is defined as the time taken for a unit impulse to } \\
\text { sipate permanently by one-half from the occurrence of the initial shock. Column ( } 3 \text { ): Median- } \\
\text { biased half-life of parity deviation, based on median-unbiased estimation of the Augmented Dickey- } \\
\text { ller regression of equation (1), as given by Andrews and Chen (1994). The half-life is as described } \\
\text { column (2) above. Column (4): "Time to peak" is the number of months following the unit shock } \\
\text { the real exchange rate that the IRF reaches its peak. Column (5): "Time to unity" is the number of } \\
\text { nths following the unit shock to the real exchange rate that the IRF crosses unity. NCU denotes non- } \\
\text { tionary series-the IRF never crosses unity. NS denotes nonstationary series-the IRF is above } \\
\text { ty, then crosses unity but does not decay. The symbol } \infty \text { denotes classic nonstationary series-the } \\
\text { F rises above unity and stays there. S denotes stationary series-the IRF never rises above unity } \\
\text { has a monotonic decay. In calculating group and all-country medians, infinity }(\infty) \text { is set to equal } \\
\text { years. }\end{array}$} \\
\hline
\end{tabular}

We conclude that the majority of countries in our sample have real exchange rates that revert (albeit sometimes slowly) to PPP and, thus, that PPP holds in the post-Bretton Woods period. Our conclusion differs from that of some previous authors, because we use an unbiased model-selection rule that has a probability of correctly selecting the unit root model (when the true $\alpha=1$ ) of about 0.5 . This contrasts with the Monte Carlo experiments of Sarno and Taylor (2002), who show that standard method yields a probability of rejecting the null hypothesis of a unit root in the real exchange rate (when the rate is, in fact, mean-reverting) of only 0.11 .

\section{Impulse Response Functions and Half-Lives of Shocks to Parity}

Figure 2 sets out the impulse-response functions (IRFs) for three country pairs: Sweden and Indonesia (which exhibit permanent shocks to their real exchange rate), the United States and Nigeria (which exhibit hump-shaped IRFs with finite half-lives), and the United Kingdom and Mexico (which exhibit monotonic decay to real exchange rate shocks and finite half-lives). The half-life can be read from the intersection of the relevant IRF with the line indicating persistence of 0.5. The 
Figure 2. Impulse-Response Function (IRF) of a Shock to the Real Effective Exchange Rate, Selected Countries, 1973:3-2002:3
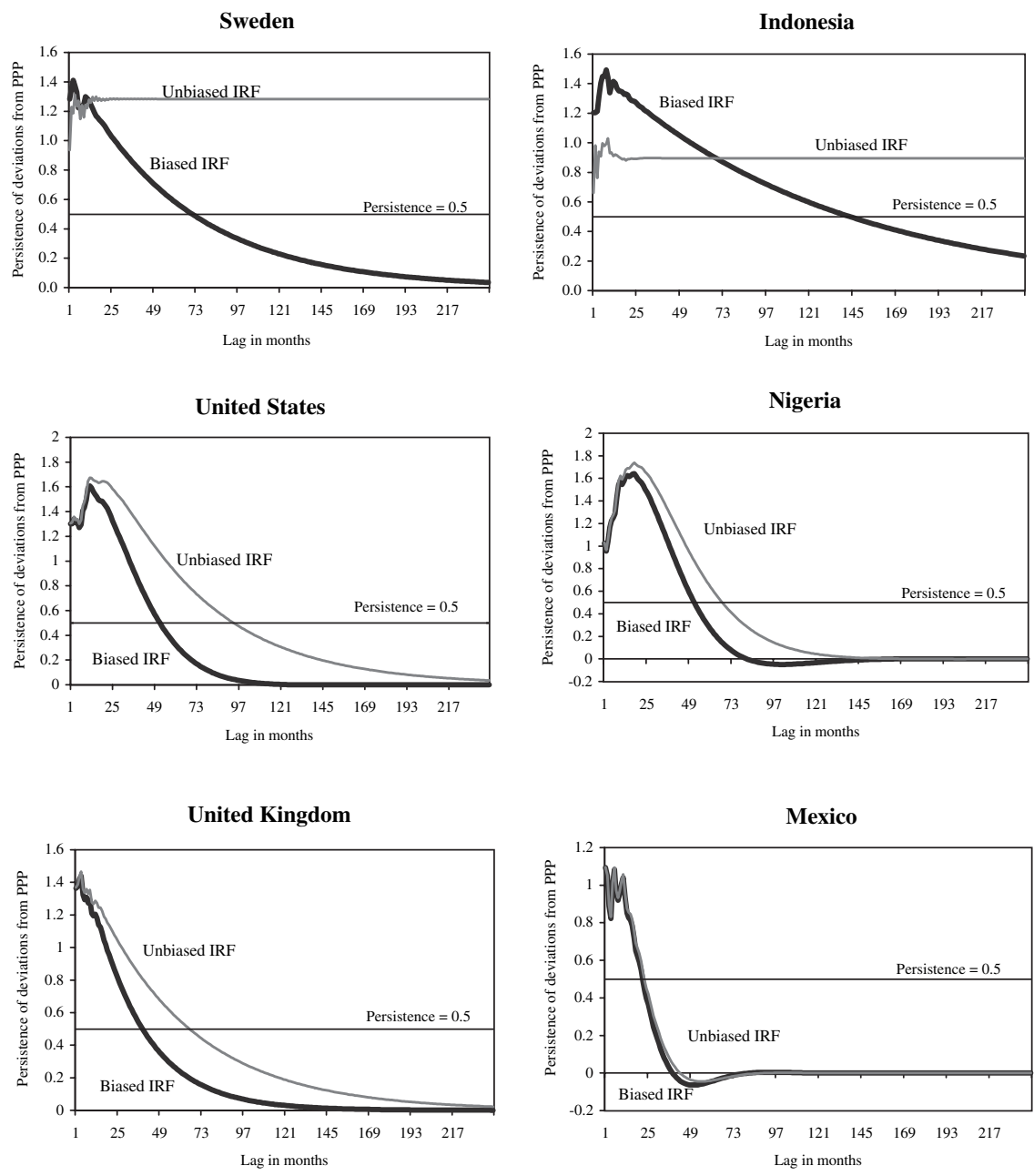

Source: Authors' calculations

impact of high-frequency noise can be seen in the first few lags of the humpshaped IRFs of the United States and Nigeria. The hump-shaped IRFs indicate that real exchange rate shocks are initially magnified. In both cases, the magnification of the real exchange rate shock can last up to one and a half years, with the IRF taking about four years to return to unity. ${ }^{9}$ As pointed out by Cheung and Lai (2000b), this nonmonotonicity in the response of the IRF to shocks results in a sig-

${ }^{9}$ Following Cheung and Lai (2000b), the effects of nonmonotonic reversion to parity can also be illustrated by calculating the half-life of real exchange rate shocks after the period of initial magnification. For both the United States and Nigeria, these modified half-life estimates are much shorter than the standard half-life of parity reversion, indicating that once the initial magnification period is completed, the IRFs dissipate rather rapidly. The duration of postmagnification half-lives can be calculated from Table 1 as the difference between the unbiased half-life (column 3) and the time to peak (column 4). 
nificant extension of the process of parity reversion (shock dissipation). Clearly, it is important to control for this kind of serial correlation in real exchange rates; while the $\operatorname{AR}(p)$ regressions can do so, standard $\operatorname{AR}(1)$ regressions assume that shocks decay monotonically and so would drastically underestimate the half-life of real exchange rate shocks.

There may be biases that offset the mean bias emanating from least squares estimation of shock persistence. Taylor (2001) contends there are two sources of upward bias in the estimation of the duration of exchange rate deviations from parity. The first is temporal aggregation bias, in which the use of low-frequency data does not allow the identification of high-frequency adjustment processes. The second is the linear AR(1) specification of unit root models, which assume monotonic reversion to parity. The use of monthly data should reduce the risk of temporal aggregation bias, while the use of an $\operatorname{AR}(p)$ model should remove the source of the second bias (see Cashin and McDermott, 2003). ${ }^{10}$

Imbs and others (2005) argue that the PPP puzzle is largely an artifact of aggregation across sectors, whereby sectoral heterogeneity in the duration of deviations from the law of one price can induce an upward bias in the speed of parity reversion of the real exchange rate derived using aggregate price indices. The Imbs and others (2005) result is to some extent controversial (see Chen and Engel, 2004), but sectoral aggregation could be a source of upward bias in the half-lives derived from both conventional and median-unbiased estimates of AR models.

In addition, the use of real effective (rather than bilateral) exchange rate data imparts another potential aggregation bias at the international level, since tradeweighted price levels are used in the calculation of a country's overall effective exchange rate. Such international aggregation could also be a source of upward bias to the estimated speed of parity reversion. However, previous work has found that the persistence properties of shocks to the real effective and bilateral exchange rate series are very similar (see McDermott, 1996).

Finally, Chen and Rogoff (2003) and Cashin, Céspedes, and Sahay (2004) point out that there are important real factors (such as real commodity export prices) that might be expected to affect the equilibrium real exchange rate of both advanced and developing countries. Both studies find that the half-life of the reversion of the real exchange rate to its (constant) long-run average level is much longer than the half-life of the reversion of the real exchange rate to its (time-varying) long-run equilibrium with real commodity prices. In this view, the long-run reversion of real exchange rates to purchasing power parity is a first approximation only (see Taylor, 2003).

\section{Cross-Country Heterogeneity of Half-Lives of Real Exchange Rate Shocks}

The results of our estimation of the median-unbiased half-life of reversion to PPP are shown in the histograms of Figures 3A to 3D. In our sample of 90 countries,

\footnotetext{
${ }^{10}$ The next step in the research agenda attempting to solve the PPP puzzle could lie in the development and implementation of median-unbiased nonlinear estimators of the speed of parity reversion.
} 
there are 50 countries for which the half-life estimates range from 1 to 14 years, and 40 countries that experience permanent real exchange rate shocks (half-lives of 29 years or more). Examining industrial countries alone, the average (median) half-life is about eight years, which is twice as long as the downward-biased estimates of previous studies (Rogoff, 1996; and Cheung and Lai, 2000a). ${ }^{11}$ In contrast, the half-life estimates for developing countries appear to be evenly spread, with most of the estimated deviations from parity being permanent. Accordingly, median-unbiased estimates of half-lives tend to be much longer for developing countries than for industrial countries. This finding of relatively slower parity reversion for developing countries contradicts the results of Cheung and Lai (2000a). However, it is consistent with Froot and Rogoff (1995), who expected that the rapid economic growth often associated with low-income countries would induce such drastic changes in the relative price of tradables and nontradables that the likelihood of parity reversion holding in any given country would rise with the level of income. Finally, the hypothesis that the real exchange rate is mean-reverting in developing countries receives some support-for 32 of 70 developing countries, the half-life of parity reversion is finite (Table 1). In contrast, the hypothesis of mean reversion of real exchange rates for developed countries receives much stronger support: 18 of 20 developed countries have real exchange rates that typically experience finite shocks.

When countries are classified by their dominant exportable, the half-life estimates for (nonfuel) primary commodity exporters appear rather dispersed (Figure $3 \mathrm{~A}$ ). This is consistent with earlier findings on the heterogeneous persistence of terms of trade shocks affecting African commodity-exporting countries (see Cashin, McDermott, and Pattillo, 2004). The average half-life for nonfuel primary-product exporters is found to be about 22 years; while finite, this implies only a very slow speed of parity reversion.

The regional grouping of developing countries reveals that shock persistence of African and Western Hemisphere countries is evenly spread between finite and permanent shocks; in contrast, permanent shocks dominate in Asian countries (Figures $3 \mathrm{~A}$ and $3 \mathrm{~B}$ ). The existing literature on parity reversion in developing countries has a sample-selection problem, as it has typically concentrated on analyses of highinflation Latin American countries. Consistent with that literature, we find that parity deviations in the often-studied countries of the Western Hemisphere (especially Brazil, Mexico, Chile, and Argentina) are rather short-lived (all with halflives of less than four years). Not surprisingly, the parity reversion half-lives for heavily indebted poor countries (HIPCs), which are mostly African, resemble the African results - the average half-life for HIPCs is found to be about 11 years.

Net debtor developing countries have also been grouped by source of external financing - for both private external financing and official external financing, real exchange rate shocks are typically permanent. Country groups of different income levels also exhibit a systematic pattern of differences in the persistence of real

${ }^{11}$ This result is also consistent with the median-unbiased half-lives calculated for industrial countries by Cashin and McDermott (2003). 
Figure 3A. Frequency Distribution of Median-Unbiased Half-Lives of Deviations from Purchasing Power Parity, Country Groups, 1973-2002

(a) All Countries

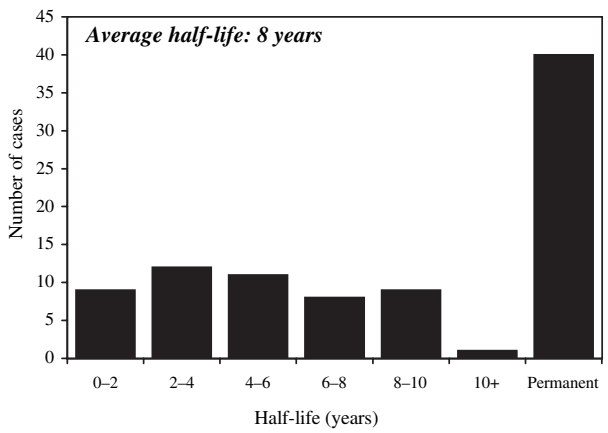

(b) Advanced Countries

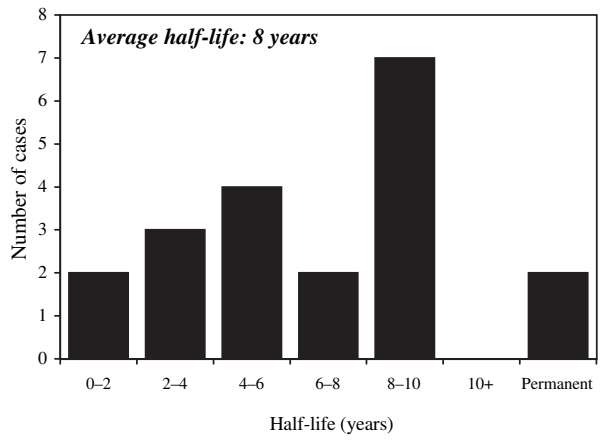

(c) Developing Countries

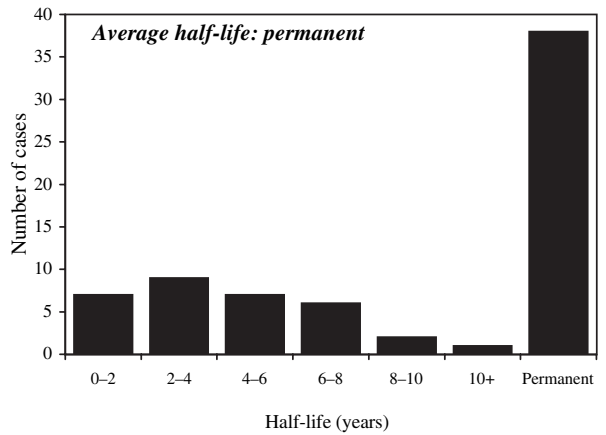

Source: Authors' calculations. (d) Nonfuel Primary-Product Exporters

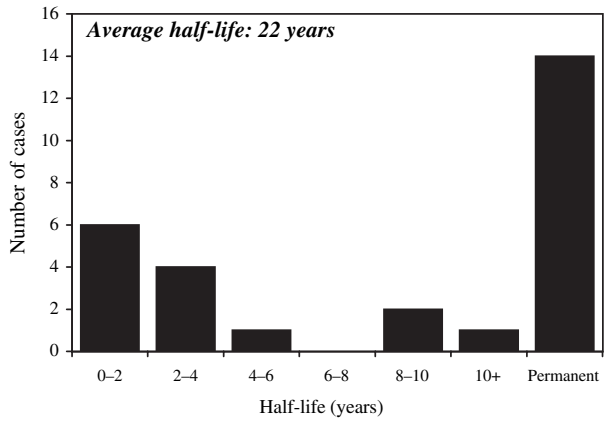

(e) Fuel Exporters

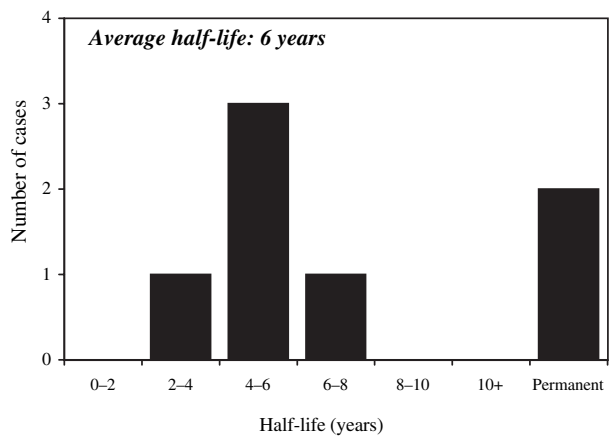

(f) African Developing Countries

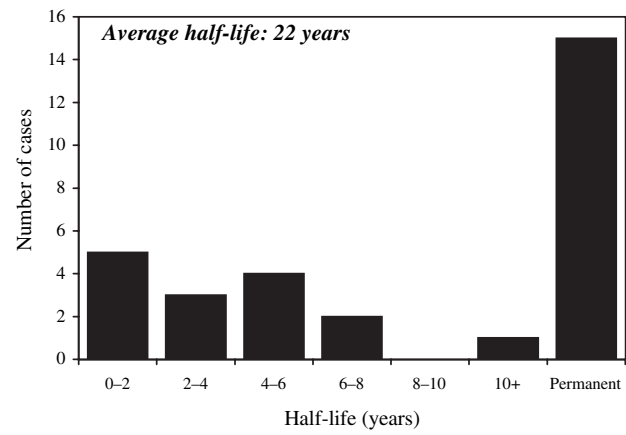

exchange rate shocks (Figure 3C)-our results tend to confirm previous work, finding an inverse relationship between income level and shock persistence (see Cheung and Lai, 2000a).

We also examine the persistence of parity deviations after classifying countries by type of nominal exchange rate regime. We classify country real exchange 
Figure 3B. Frequency Distribution of Median-Unbiased Half-Lives of Deviations from Purchasing Power Parity, Country Groups, 1973-2002

(g) Asian Developing Countries

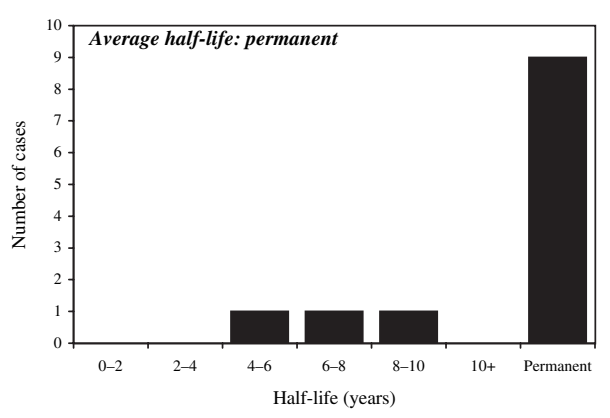

(h) Middle East and Turkey Developing Countries

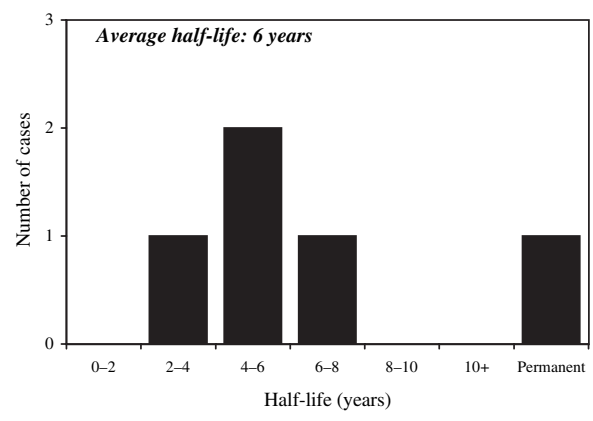

(i) Western Hemisphere Developing Countries

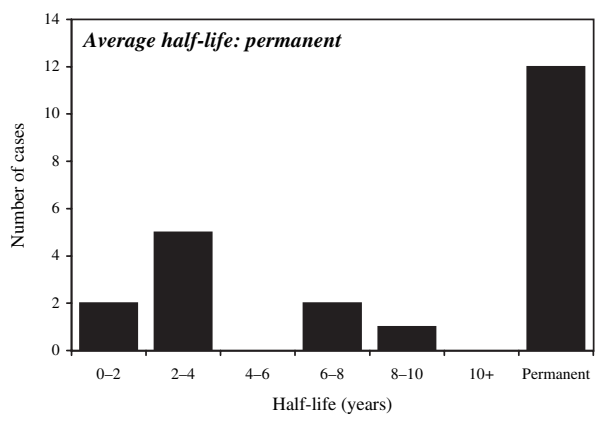

Source: Authors' calculations. (j) Developing Countries: Net Debtor Countries, Private External Financing

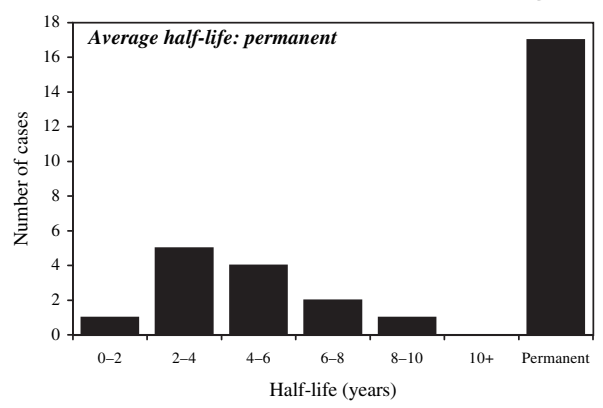

(k) Developing Countries: Net Debtor Countries, Official External Financing

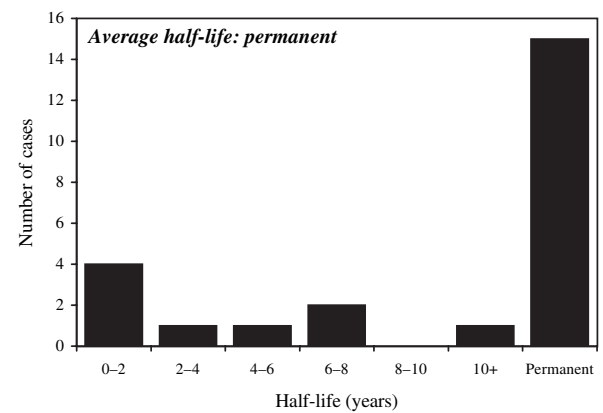

(l) Heavily Indebted Poor Countries

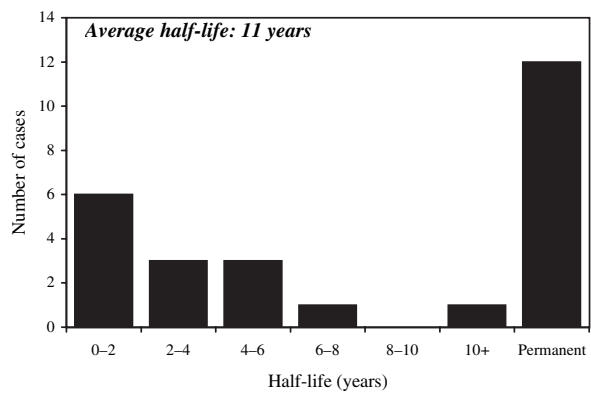

rates by type of nominal exchange rate regime, using (1) the IMF's (1998) de jure classification, which is based on the publicly stated commitment of the authorities of the country in question; and (2) the de facto classification of Reinhart and Rogoff (2002), which is based on the observed behavior of market-determined real exchange rates, including that of active parallel exchange rate markets. It is important to examine both de facto and de jure exchange rates because, through exchange 
Figure 3C. Frequency Distribution of Median-Unbiased Half-Lives of Deviations from Purchasing Power Parity, Country Groups, 1973-2002

(m) Countries with Annual Income $\$ 102$ - \$280 (real GDP per capita, 1995 U.S. dollars)

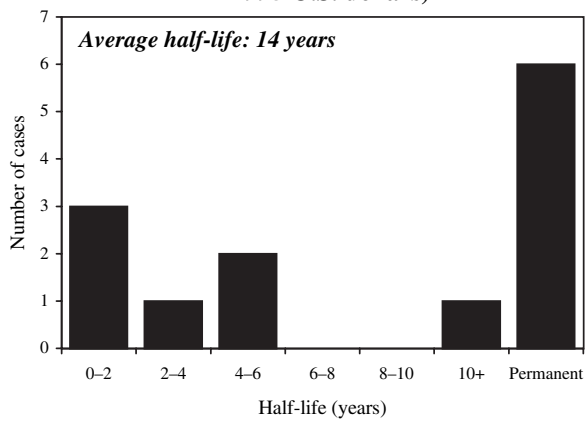

(n) Countries with Annual Income \$281 - \$769 (real GDP per capita, 1995 U.S. dollars)

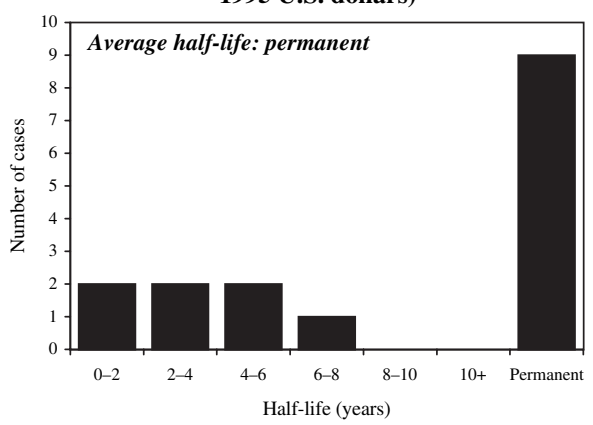

(o) Countries with Annual Income \$770 - \$2,111 (real GDP per capita, 1995 U.S. dollars)

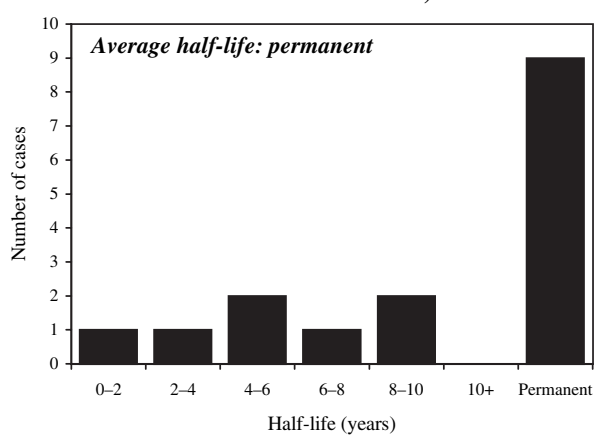

Source: Authors' calculations. (p) Countries with Annual Income

$\$ 2,112$ - \$5,792 (real GDP per capita, 1995 U.S. dollars)

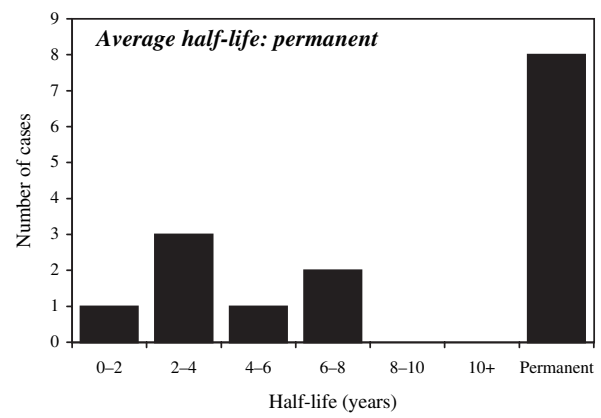

(q) Countries with Annual Income $\$ 5,793$ - $\$ 15,891$ (real GDP per capita, 1995 U.S. dollars)

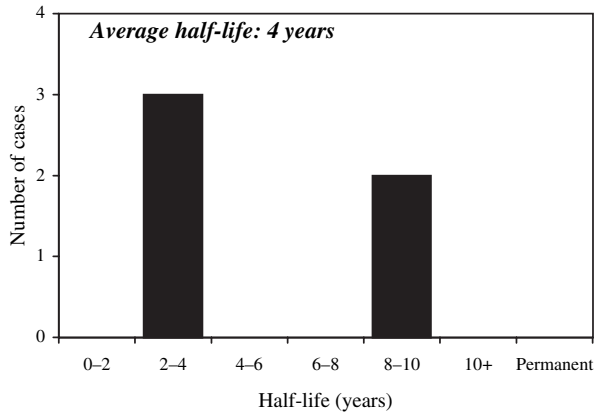

(r) Countries with Annual Income $\$ 15,892$ - $\$ 43,600$ (real GDP per capita, 1995 U.S. dollars)

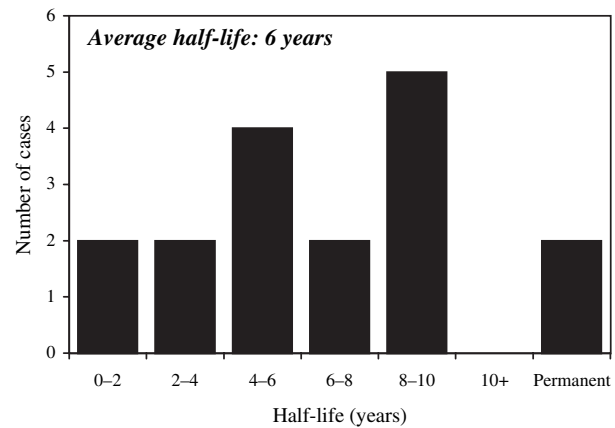


market intervention or monetary policy, the authorities of a country can transform a de jure flexible exchange rate regime into a de facto pegged regime. Similarly, active parallel markets can transform de jure pegged official exchange rates into de facto flexible regimes.

When all 90 countries are categorized by the IMF's (1998) de jure exchange rate classification rules, it is clear that pegged exchange rate countries typically experience permanent deviations from parity, while more flexible exchange rate countries have much more dispersed half-lives of deviations from parity (Figure 3D). Very similar results are derived when exchange rates are classified using the Reinhart and Rogoff (2002) de facto exchange rate classification. The de facto classification reveals that while permanent real exchange rate shocks dominate the experience of pegged exchange rate countries, parity deviations for the majority of flexible exchange rate countries are finite and typically range between 2 and 10 years.

\section{What Is Causing the Heterogeneous Persistence of Deviations from Parity?}

Underpinning the fundamental idea of long-run PPP is the notion that arbitrage in goods ensures that the parity condition is satisfied across a range of goods over a certain period. A key question is what might be causing the heterogeneous duration of exchange rate deviations from parity. In particular, in this section we will investigate the differences in the speed of parity reversion among advanced (industrial) and developing countries, and among countries with fixed and flexible nominal exchange rate regimes. Following Cheung and Lai (2000a), we examine whether the observed pattern of the persistence of real exchange rate shocks can be linked to any systematic differences in structural characteristics across countries.

Given that the usual distributional assumption of normality is not likely to hold for the distribution of either the half-lives of deviations from parity or the structural characteristics of countries, we use several nonparametric tests to examine the statistical significance of various hypotheses. These tests concern the equality of the average duration of parity deviations across country groups; the equality of the variability of the average duration of parity deviations across country groups; and whether the pattern of persistence of parity deviations is correlated with countries' structural characteristics.

First, we implement a nonparametric test of the equality of the median half-life of deviations from parity across country groups (the Wilcoxon-Mann-Whitney test). The results (listed in column 4 of Table 2) indicate that the null hypothesis of equal median half-lives is rejected, at the 5 percent significance level, for advanced versus developing countries. Further, the null hypothesis of equal median half-lives is rejected, at the 5 percent significance level, for pegged versus flexible exchange rate countries (classified under either the IMF (1998) or Reinhart and Rogoff (2002) classification scheme). Accordingly, we conclude that the average half-life of real exchange rate deviations from parity for advanced (industrial) countries is shorter in duration than the average for developing countries. In addition, the average half-life for countries with pegged nominal exchange rates is significantly longer in duration than that for countries with flexible nominal exchange rates. 
Figure 3D. Frequency Distribution of Median-Unbiased Half-Lives of Deviations from Purchasing Power Parity, Country Groups, 1973-2002

(s) IMF AREAER (dejure): Pegged Exchange Rate Countries

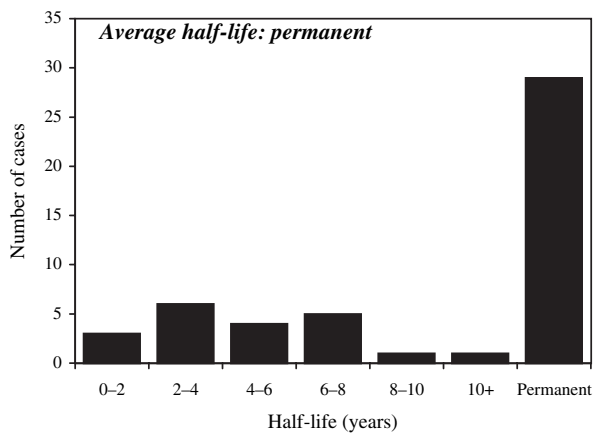

(t) IMF AREAER (dejjure): Intermediate Exchange Rate Countries

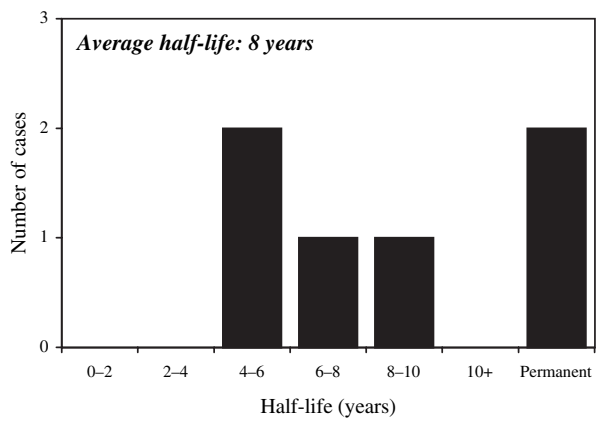

(u) IMF AREAER (de jure): Flexible Exchange Rate Countries

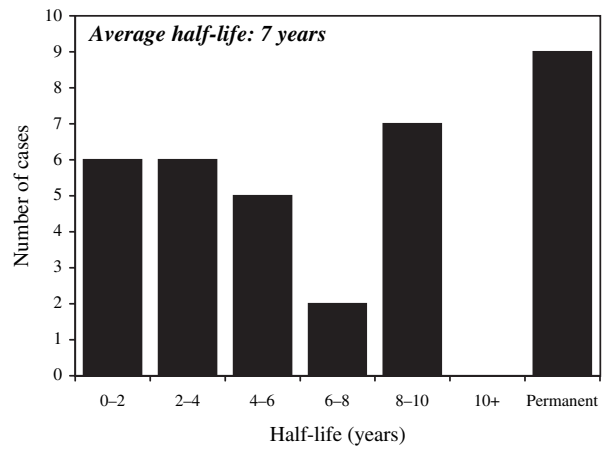

Source: Authors' calculations. (v) Reinhart-Rogoff (de facto): Pegged Exchange Rate Countries

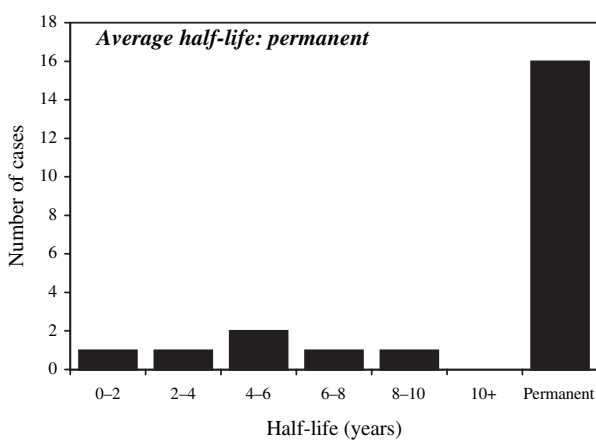

(w) Reinhart-Rogoff (de facto): Limited Flexibility and Managed Float Exchange Rate Countries

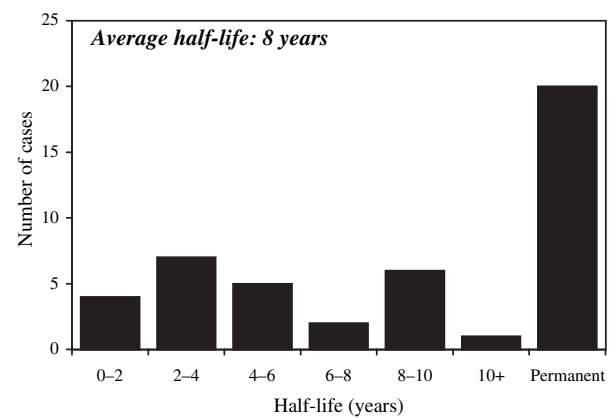

(x) Reinhart-Rogoff (de facto): Freely Floating/Falling Exchange Rate Countries

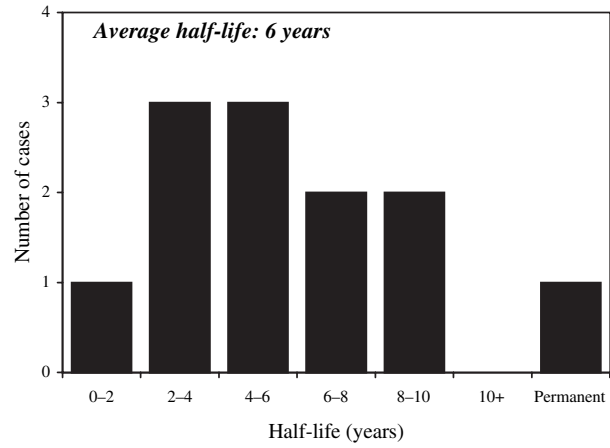

When examining the persistence of real exchange rate shocks, the statistical significance of the difference of the group medians confirms the pattern shown in Figures 3A-3D-industrial countries display less persistence than developing 
Table 2. Descriptive Statistics of Persistence of PPP Deviations, Country Groups

\begin{tabular}{|c|c|c|c|c|}
\hline $\begin{array}{l}\text { Country Group } \\
\text { (1) }\end{array}$ & $\begin{array}{c}\text { Average } \\
\text { Persistence of } \\
\text { Deviations from } \\
\text { PPP (years) } \\
\text { (2) }\end{array}$ & $\begin{array}{l}\text { Number of } \\
\text { Observations } \\
\text { per Country } \\
\text { Group } \\
\text { (3) }\end{array}$ & $\begin{array}{c}H_{0} \text { : Equality } \\
\text { of Median } \\
\text { Deviation from } \\
\text { PPP ( } p \text {-value) } \\
\text { WMW test } \\
(4)\end{array}$ & $\begin{array}{l}H_{0} \text { : Equality } \\
\text { of Variance of } \\
\text { Deviation from } \\
\text { PPP ( } p \text {-value) } \\
\text { BF test } \\
\text { (5) }\end{array}$ \\
\hline All countries & 8.17 & 90 & & \\
\hline Advanced & 7.67 & 20 & & \\
\hline Developing & 30.00 & 70 & $2.18(0.029)$ & $6.11(0.015)$ \\
\hline \multicolumn{5}{|l|}{$\begin{array}{l}\text { IMF de jure } \\
\text { classification: }\end{array}$} \\
\hline Peg & 30.00 & 49 & & \\
\hline Flexible & 7.25 & 35 & $2.73(0.006)$ & $0.68(0.413)$ \\
\hline \multicolumn{5}{|l|}{$\begin{array}{l}\text { Reinhart-Rogoff de } \\
\text { facto classification: }\end{array}$} \\
\hline Peg & 30.00 & 22 & & \\
\hline Free-floating/falling & 5.58 & 12 & $3.22(0.001)$ & $0.67(0.418)$ \\
\hline \multicolumn{5}{|c|}{$\begin{array}{l}\text { Source: Authors' calculations. } \\
\text { Notes: Column (1): Country group; for definition and derivation, see Appendix II. Column (2): } \\
\text { rsistence of deviations from PPP is calculated as the group average (median) half-life (in years) of } \\
\text { viations of the real exchange rate from parity. Column (3): Number of observations is the number of } \\
\text { antries in each country group. Column (4): WMW is the Wilcoxon-Mann-Whitney test statistic of the } \\
11 \text { hypothesis of equality of the median half-life of deviations from PPP for each country group; the } \\
\text { alue is for the asymptotic normal approximation to the Wilcoxon } t \text {-statistic (see Conover, 1999). } \\
\text { lumn (5): BF is the Brown-Forsythe test statistic of the null hypothesis of equality of the variance of } \\
\text { median half-life of deviations from PPP for each country group. The } F \text {-statistic for the BF test has } \\
\text { approximate } F \text {-distribution with } G=1 \text { numerator degrees of freedom and } N-G \text { denominator degrees } \\
\text { freedom, under the null of equal variances in each group, where } G \text { is the number of groups and } N \text { the } \\
\text { mber of observations; the approximate } p \text {-value is given in parentheses. }\end{array}$} \\
\hline
\end{tabular}

countries, and countries with fixed nominal exchange rate regimes display more persistence than countries with flexible nominal exchange rate regimes.

Second, we examine whether the differences in the sample variances of the half-lives across country groups are statistically significant by implementing the Brown-Forsythe test. The results (listed in column 5 of Table 2) indicate that the null hypothesis of equal variances of the half-lives is rejected, at the 5 percent significance level, for the industrial countries in comparison with the developing countries. Interestingly, the null of equality of the variances of the half-lives across pegged and flexible exchange rate regimes cannot be rejected. Accordingly, there is evidence that the duration of half-lives of parity deviations for developing countries is more variable than the duration of half-lives of parity deviations for industrial countries.

Third, we use our cross-country data to examine whether each country's persistence of deviations from parity is correlated with its structural characteristics. As normality is unlikely to hold here, we again use a nonparametric test- the 
Spearman rank correlation test (see Cheung and Lai (2000a) and Conover (1999) for details). The Spearman rank correlation test measures whether there is a significant relationship between the persistence of parity deviations and key structural characteristics (such as cross-country differentials in inflation and trade openness). The null hypothesis of the Spearman rank correlation test is that there is no rank correlation between the persistence of parity deviations and differentials in each country's structural characteristics. In explaining empirical cross-country heterogeneity in the duration of real exchange rate deviations from parity, we will evaluate several fundamental characteristics (see Appendix I for details), including cross-country differentials in inflation (INF), nominal exchange rate arrangements (VOFFER and VPARER), openness to trade (TGDP), productivity growth (PCGDP), and the share of government spending in the economy (GGDP).

\section{Inflation}

If national price movements were dominated by nominal (monetary) shocks, then parity reversion would be expected to be rather fast. Given the presence of nominal rigidities, a higher inflation rate may bring about more frequent adjustment of goods prices and shrink the duration of deviations from parity. Indeed, previous work has indicated that PPP typically holds for high-inflation countries (Frenkel, 1978; and McNown and Wallace, 1989). To analyze whether relative inflation is related to cross-country differences in persistence of parity deviations, we construct the average (median) inflation rate over the sample period (INF) for each country. The rank correlation coefficient between the half-life of the real exchange rate and the rate of inflation is -0.281 , with an approximate $p$-value of 0.007 (Table 3 ). Using the critical values of Zar (1972), the null of no rank correlation is decisively rejected, with the rank correlation being negative and statistically significant at the 1 percent level. This indicates that, across advanced and developing countries, there is an inverse relationship between inflation and the persistence of real exchange rate shocks. That is, countries with higher inflation rates tend to have shorter lived deviations of their real exchange rates from PPP, which suggests that parity reversion is fast when price movements largely reflect monetary shocks.

\section{Nominal Exchange Rate Volatility}

Mussa (1986) stressed that exchange rates behaved differently under alternative exchange rate regimes, finding that the post-Bretton Woods float of major currencies had induced large real exchange rate variability in many industrial countries. Greater flexibility in nominal exchange rates would be expected to increase the speed of parity reversion of real exchange rates by encouraging more frequent adjustment of goods prices. However, as noted above, it is important to measure the variability of nominal exchange rates using both the official exchange rate (VOFFER) and the exchange rate determined in parallel markets (VPARER). In doing so, we use both the official and parallel exchange rate market data of Reinhart and Rogoff (2002) for the period 1973-98, with variability measured as the standard deviation of the (monthly) rate of change of the (log) series. 


\section{Table 3. Rank Correlation of Half-Life of Deviation from Purchasing Power Parity with Country Characteristics, All Countries \\ Country Characteristic \\ (1) \\ Rate of inflation \\ Volatility of the official nominal exchange rate \\ Volatility of the parallel-market nominal exchange rate \\ Productivity growth \\ Government spending \\ Trade openness \\ Rank Correlation of Characteristic with Half-Life of Parity Deviations \\ $-0.281 *$ \\ $-0.379 *$ \\ $-0.282 *$ \\ $-0.038$ \\ $-0.073$ \\ 0.180 \\ Approximate $p$-Value (number of observations) \\ $0.007(90)$ $0.002(70)$ $0.02(70)$ \\ $0.77(90)$ \\ $0.50(88)$ \\ $0.10(89)$}

Source: Authors' calculations.

Notes: Column (1): Country characteristic; for definition and derivation, see Appendix I. Column (2): Spearman rank correlation coefficient—-the null hypothesis of the Spearman test is that there is no correlation between the (tie-adjusted) rank of each country's bias-corrected half-life of parity deviation and the rank of its period-average value of the country characteristic. Persistence of deviations from PPP is calculated as the median-unbiased half-life (in years) of real exchange rate deviations from parity (listed in column 3 of Table 1). Column (3): The approximate $p$-value is taken from Zar (1972). An asterisk (*) denotes that the null hypothesis of no rank correlation is rejected at the 5 percent level of significance. The number of country observations is given in parentheses.

The rank correlation coefficient between the half-life of the real exchange rate and the variability of the official nominal exchange rate is -0.379 , with an approximate $p$-value of 0.002 (Table 3). Similarly, the rank correlation coefficient between the half-life of the real exchange rate and the variability of the parallel-market nominal exchange rate is -0.282 , with an approximate $p$-value of 0.02 . Both correlations are negative and statistically significant at the 1 percent level. This indicates that, across advanced and developing countries, there is an inverse relationship between nominal exchange rate variability and the persistence of real exchange rate shocks; that is, countries with more variable nominal exchange rates tend to have shorter lived deviations of their real exchange rates from PPP. These results are broadly consistent with the conclusions of Goldfajn and Valdés (1999), who find that overvaluation of real exchange rates was typically corrected by changes in the nominal exchange rate rather than changes in inflation differentials.

\section{Productivity Growth and Government Spending}

Productivity growth is a supply-side factor that can affect the persistence of real exchange rate shocks. The Balassa-Samuelson effect has traditionally been the most popular explanation for the persistence of parity deviations. The BalassaSamuelson hypothesis highlights the potential effects of differential productivity growth (favoring the traded goods sector) on the behavior of real exchange rates, which ultimately raises the relative price of nontraded goods. Importantly, this 
traded-goods productivity bias is deemed to rise with the wealth of the country. Following Balassa (1964), we proxy for productivity growth by using the rate of growth of per capita real GDP; accordingly, we construct the average (median) per capita growth rate over the sample period for each country (PCGDP).

In the presence of capital and labor that are mobile across sectors in the long run but not the short run, government spending is a demand-side factor that is also hypothesized to affect the speed of parity reversion by producing a stronger homegoods bias. Froot and Rogoff (1991) note that government spending typically falls more heavily on nontraded goods, thereby bidding up their price relative to the price of tradables. Bergin and Feenstra (2001) suggest that real exchange rate persistence rises with the share of produced goods that are nontraded. Accordingly, we construct the average (median) for government spending as a share of GDP over the sample period for each country (GGDP).

The rank correlation coefficient between the half-life of the real exchange rate and the growth of per capita GDP is -0.038 , with an approximate $p$-value of 0.77 (Table 3). Similarly, the rank correlation coefficient between the half-life of the real exchange rate and government spending as a share of GDP is -0.073 , with an approximate $p$-value of 0.50 . Neither rank correlation is significantly different from zero. We thus conclude that there is little evidence that either higher productivity growth or greater government spending can explain much of the observed pattern of deviation from PPP across countries. Our conclusions are consistent with those of Rogoff (1996).

\section{Trade Openness}

Rogoff, Froot, and Kim (2001) highlight the effect of goods market arbitrage, which, if operative, can accelerate the speed of parity reversion across goods. Greater trade flows should, in principle, promote goods market arbitrage, encourage more frequent price adjustment by firms, and reduce the persistence of real exchange rate shocks (Faruqee, 1995). As a measure of trade openness, we construct for each country over the sample period the average (median) ratio of exports plus imports to GDP (TGDP). The rank correlation coefficient between the halflife of the real exchange rate and external trade as a share of GDP is 0.180 , with an approximate $p$-value of 0.10 (Table 3 ). This rank correlation differs insignificantly from zero. Accordingly, there is little evidence in favor of the goods arbitrage view of PPP - differences in trade openness are not associated with the persistence of parity deviations across countries. ${ }^{12}$

To summarize, we find that cross-country differences in inflation rates and nominal exchange rate variability have a strong and statistically significant inverse relationship with the observed pattern of the persistence of deviations from purchasing

\footnotetext{
${ }^{12}$ Cheung, Chinn, and Fujii (2001) also find a nonnegative relationship between openness and the persistence of sectoral real exchange rate deviations. They attribute this result to the inverse relationship between openness and inflation (see Romer, 1993). For our sample of countries, we also find a strong negative rank correlation between openness and inflation $(-0.397)$. This suggests that greater openness is associated with lower inflation, which implies a slower speed of parity reversion.
} 
power parity. ${ }^{13}$ Indeed, to the extent that the existing literature on measuring parity reversion in developing countries has largely concentrated on the Latin American experience (which is dominated by high-inflation countries), this sample-selection bias can account for the erroneous received wisdom that parity reversion in developing countries is faster than that observed for developed countries. However, once a wider set of developing countries is analyzed, parity reversion in developing countries is typically slower than that observed for developed countries.

\section{Conclusion}

The validity of purchasing power parity (PPP) — the notion that prices in different countries move toward equality in common currency terms - is of interest to policymakers for two main reasons. First, PPP provides a long-term benchmark for the equilibrium value of exchange rates and, as such, is a criterion for evaluating the competitiveness of real exchange rates. Second, PPP has been adopted as a central building block of many theories of exchange rate determination; the quality of policy advice based on these theories may depend on the validity of PPP.

This paper has reexamined whether PPP holds during the post-Bretton Woods period by investigating the time series properties of the real effective exchange rate of 90 advanced and developing countries. The post-1973 revival of flexible exchange rates spawned a great interest in the empirical relevance of the PPP theory of real exchange rate determination. Previous studies of PPP reversion largely focused on developed countries, and univariate studies of the hypothesis of unit roots in real exchange rates yielded consensus estimates of the half-life of deviations of real exchange rates from PPP of about four years (Rogoff, 1996).

Using least squares estimation of unit root models, we replicate the consensus finding in the literature. However, using median-unbiased estimation techniques that remove the downward bias of least squares, we find that the half-lives of parity reversion are much longer than the consensus estimate, with a cross-country average of bias-corrected half-lives of about eight years. Our results confirm Rogoff's (1996) "PPP puzzle" - that while PPP holds for the majority of countries, the reversion of real exchange rates to parity is, in many cases, rather slow.

Using the median-unbiased estimates of the half-lives of deviations from parity and the Andrews (1993) unbiased model-selection rule, we conclude that 50 of the 90 countries in our sample have finite half-lives of parity reversion, which indicates that there is a better than even chance that shocks to their real exchange rates are transitory. For these 50 countries, we can conclude that there is reversion of real exchange rates to parity and that PPP holds in the post-Bretton Woods period. Conversely, there is little evidence of parity reversion for the remaining 40 countries in our sample, where shocks to the real exchange rate are best viewed as being permanent.

\footnotetext{
${ }^{13}$ As a robustness check on the unconditional correlation results, least squares regression of the half-life of parity deviation on the above-mentioned structural characteristics was also carried out. As in the bivariate correlations, inflation is the most significant variable for reducing the half-life of parity deviations.
} 
Our analysis yields evidence of significant heterogeneity of parity reversion across countries and across groups of countries. In our view, the general relevance of parity reversion has been exaggerated by the predilection of studies to focus on the reversion experience of developed countries. In addition, the few studies of parity reversion for developing countries have suffered from sample-selection bias, in that they typically examined the speed of reversion in high-inflation Latin American countries. We find that parity reversion is more likely to be found for developed countries than for developing countries. Parity reversion is also more likely to be found for countries with flexible nominal exchange rate regimes than for countries with fixed nominal exchange rate regimes. Finally, when we examine the determinants of the observed cross-country heterogeneity in the persistence of reversion of real exchange rates to parity, we find that parity reversion tends to be faster in high-inflation countries than in low-inflation countries and slower in countries with less nominal exchange rate variability.

\section{APPENDIX I}

\section{Description of the Data}

The primary data sources are the IMF's International Financial Statistics (IFS) and Information Notice System (INS), Reinhart and Rogoff (2002), and the World Bank's World Development Indicators (2002). Below we provide a description of each series used in the paper. The 90 developing and developed countries in the full sample are listed in Table 1. Unless otherwise noted, the data are for the sample period 1973-2002.

REER: The real effective exchange rate data are of monthly frequency, for the period March 1973-March 2002; a total of 358 observations. REER is the trade-weighted measure of the seasonally adjusted, CPI-based real effective exchange rate (base 1990=100); obtained from the IMF's INS.

INF: The rate of change of consumer prices (percent a year); period average of annual data 1973-2002; obtained from the IMF's IFS.

GGDP: General government final consumption spending as a share of GDP; period average of annual data 1973-2002; obtained from World Bank (2002).

PCGDP: Growth of per capita GDP (percent per annum); period average of annual data, 1973-2002; obtained from World Bank (2002).

TGDP: Exports and imports of goods and services (valued in current U.S. dollars) as a share of GDP (valued in current U.S. dollars); period average of annual data, 1973-2002; obtained from World Bank (2002).

VPARER: Volatility of the parallel market exchange rate; measured as the standard deviation of the (monthly) rate of change of the parallel market exchange rate, with the exchange rate measured as the logarithm of the parallel nominal exchange rate (local currency per U.S. dollar), March 1973 to December 1998; obtained from Reinhart and Rogoff (2002).

VOFFER: Volatility of the official exchange rate; measured as the standard deviation of the (monthly) rate of change of the official exchange rate, with the exchange rate measured as the logarithm of the official nominal exchange rate (local currency per U.S. dollar), March 1973 to December 1998; obtained from Reinhart and Rogoff (2002). 


\section{Nominal Exchange Rate Regime}

The IMF's de jure classification, used between 1975 and 1997 in its Annual Report on Exchange Arrangements and Exchange Restrictions (AREAER), consisted of 10 categories grouped as follows: regimes 1-5 are defined as fixed pegs; regimes 6-7 (limited flexibility with respect to a single currency, cooperative arrangements) are intermediate; and regimes 8-10 (including managed floating and independently floating) are flexible arrangements. For each country, the de jure exchange rate regime classification is the mode of the AREAER classification numbers over the period 1975-98. See Bubula and Otker-Robe (2002) for details.

The Reinhart and Rogoff (2002) de facto classification describes exchange rate regimes as: (1) de facto pegs (including no separate legal tender and currency boards), denoted as regime 1; (2) limited flexibility (including crawling pegs and narrow crawling bands), denoted as regime 2; (3) managed floating (including wider crawling bands), denoted as regime 3; (4) freely floating, denoted as regime 4; and (5) freely falling (where the annualized rate of inflation exceeds 40 percent), denoted as regime 5 . For each country, the de facto exchange rate regime classification is the mode of the annual Reinhart and Rogoff (2002) classification numbers over the period 1973-98. The following countries had no Reinhart and Rogoff (2002) classification data: Barbados, the Democratic Republic of the Congo, Ethiopia, Fiji, Papua New Guinea, Rwanda, Samoa, Seychelles, Sierra Leone, Sudan, and Trinidad and Tobago.

\section{APPENDIX II}

\section{Country Group Classifications}

The 90 developed and developing countries in our sample (listed in Table 1) have been classified into various country groups in order to undertake cross-country comparisons of the persistence of parity deviations. The major sources of classification were the IMF's World Economic Outlook (2002, 2000); the IMF's Annual Report on Exchange Arrangements and Exchange Restrictions (AREAER), various issues; the World Bank's World Development Indicators database (2002); Andrews and others (1999); and Reinhart and Rogoff (2002). The country groups, along with the country members and classification rule, follow.

The IMF's World Economic Outlook (2002) classifies countries into groups on the basis of certain criteria. For nondeveloping countries, the groups are advanced economies and countries in transition. Developing countries are classified by their predominant export. Primary product exporters are those countries whose exports of agricultural and mineral primary products (Standard Industrial Trade Classification (SITC) 0, 1, 2, 4, 68) accounted for at least 50 percent of their total export earnings during 1994-98. Fuel exporters are those countries whose exports of fuel products (SITC 3) accounted for at least 50 percent of their total export earnings during 1994-98. Net debtor countries are defined as developing countries with negative external assets at the end of 1998. Net debtor countries are then differentiated by their main source of external financing: Those with official financing (including official grants) accounting for more than two-thirds of their total 1994-98 external financing are classified as official external financing countries; and those with private financing (including direct and portfolio investment) accounting for more than two-thirds of their total 1994-98 external financing are classified as private external financing countries.

Advanced economies: Australia, Austria, Belgium, Canada, Finland, Germany, Iceland, Ireland, Italy, Japan, Korea, Netherlands, New Zealand, Norway, Portugal, Spain, Sweden, Switzerland, United Kingdom, and United States (IMF (2002) classification).

Developing countries: Argentina, Barbados, Bolivia, Brazil, Burkina Faso, Cameroon, Central African Republic, Chad, Chile, Colombia, Democratic Republic of the Congo, Republic of 
Congo, Côte d'Ivoire, Costa Rica, Dominican Republic, Ecuador, Egypt, El Salvador, Ethiopia, Fiji, Gabon, The Gambia, Ghana, Guatemala, Guyana, Haiti, Honduras, Hungary, India, Indonesia, Islamic Republic of Iran, Jamaica, Kenya, Lesotho, Madagascar, Malawi, Malaysia, Malta, Mauritania, Mauritius, Mexico, Morocco, Myanmar, Nepal, Niger, Nigeria, Pakistan, Panama, Papua New Guinea, Paraguay, Peru, Philippines, Rwanda, Samoa, Senegal, Seychelles, Sierra Leone, Sri Lanka, Sudan, Syria, Tanzania, Thailand, Togo, Trinidad and Tobago, Tunisia, Turkey, Uganda, Uruguay, República Bolivariana de Venezuela, and Zambia (IMF (2002) classification).

Nonfuel primary-product exporting countries: Australia, Bolivia, Burkina Faso, Canada, Central African Republic, Chad, Chile, Democratic Republic of the Congo, Cote d'Ivoire, The Gambia, Ghana, Guyana, Honduras, Iceland, Madagascar, Malawi, Mauritania, Myanmar, New Zealand, Niger, Papua New Guinea, Paraguay, Peru, Sudan, Tanzania, Togo, and Zambia (IMF (2002) classification).

Fuel-exporting countries: Republic of Congo, Gabon, Islamic Republic of Iran, Nigeria, Norway, Trinidad and Tobago, and República Bolivariana de Venezuela (IMF (2002) classification).

African developing countries: Burkina Faso, Cameroon, Central African Republic, Chad, Democratic Republic of the Congo, Republic of Congo, Côte d'Ivoire, Ethiopia, Gabon, The Gambia, Ghana, Kenya, Lesotho, Madagascar, Malawi, Mauritania, Mauritius, Morocco, Niger, Nigeria, Rwanda, Senegal, Seychelles, Sierra Leone, Sudan, Tanzania, Togo, Tunisia, Uganda, and Zambia (IMF (2002) classification).

Asian developing countries: Fiji, India, Indonesia, Malaysia, Myanmar, Nepal, Pakistan, Papua New Guinea, Philippines, Samoa, Sri Lanka, and Thailand (IMF (2002) classification).

Western Hemisphere developing countries: Argentina, Barbados, Bolivia, Brazil, Chile, Colombia, Costa Rica, Dominican Republic, Ecuador, El Salvador, Guatemala, Guyana, Haiti, Honduras, Jamaica, Mexico, Panama, Paraguay, Peru, Trinidad and Tobago, Uruguay, and República Bolivariana de Venezuela (IMF (2002) classification).

Middle East and Turkey developing countries: Egypt, Islamic Republic of Iran, Malta, Syria, and Turkey (IMF (2002) classification).

Heavily indebted poor countries (HIPCs): Comprises those countries (except Nigeria) considered by the IMF and World Bank for their HIPC debt initiative-Bolivia, Burkina Faso, Cameroon, Central African Republic, Chad, Democratic Republic of the Congo, Republic of Congo, Côte d'Ivoire, Ethiopia, Ghana, Guyana, Honduras, Kenya, Madagascar, Malawi, Mauritania, Myanmar, Niger, Rwanda, Senegal, Sierra Leone, Sudan, Tanzania, Togo, Uganda, and Zambia (IMF (2002) classification; see Andrews and others, (1999)).

Developing countries-net debtor countries, private external financing: Argentina, Brazil, Chile, Colombia, Costa Rica, Dominican Republic, Ecuador, Egypt, Fiji, Guatemala, India, Indonesia, Islamic Republic of Iran, Jamaica, Kenya, Lesotho, Malaysia, Malta, Mexico, Morocco, Myanmar, Panama, Paraguay, Peru, Seychelles, Sierra Leone, Thailand, Trinidad and Tobago, Turkey, and República Bolivariana de Venezuela (IMF (2000) classification).

Developing countries-net debtor countries, official external financing: Burkina Faso, Cameroon, Central African Republic, Chad, Democratic Republic of the Congo, Republic of Congo, Ethiopia, Gabon, The Gambia, Guatemala, Guyana, Haiti, Madagascar, Malawi, Mauritania, Nepal, Niger, Rwanda, Samoa, Senegal, Tanzania, Togo, Uganda, and Zambia (IMF (2000) classification). 
Countries with annual income (real GDP per capita in U.S. dollars in 1995) of \$102-\$280: Burkina Faso, Chad, Democratic Republic of the Congo, Ethiopia, Madagascar, Malawi, Nepal, Niger, Nigeria, Rwanda, Sierra Leone, Sudan, and Tanzania (World Bank (2002) classification).

Countries with annual income (real GDP per capita in U.S. dollars in 1995) of \$281-\$769: Cameroon, Central African Republic, Côte d'Ivoire, The Gambia, Ghana, Haiti, Honduras, India, Kenya, Mauritania, Pakistan, Senegal, Sri Lanka, Togo, Uganda, and Zambia (World Bank (2002) classification).

Countries with annual income (real GDP per capita in U.S. dollars in 1995) of \$770-\$2,111: Bolivia, Republic of Congo, Dominican Republic, Ecuador, Egypt, El Salvador, Guatemala, Indonesia, Islamic Republic of Iran, Jamaica, Morocco, Papua New Guinea, Paraguay, Philippines, Syria, and Tunisia (World Bank (2002) classification).

Countries with annual income (real GDP per capita in U.S. dollars in 1995) of \$2,112-\$5,792: Brazil, Chile, Colombia, Costa Rica, Gabon, Hungary, Malaysia, Mauritius, Mexico, Peru, Thailand, Trinidad and Tobago, Turkey, Uruguay, and República Bolivariana de Venezuela (World Bank (2002) classification).

Countries with annual income (real GDP per capita in U.S. dollars in 1995) of \$5,793\$15,891: Argentina, Barbados, Korea, Portugal, and Spain (World Bank (2002) classification).

Countries with annual income (real GDP per capita in U.S. dollars in 1995) of \$15,892-\$43,600: Australia, Austria, Belgium, Canada, Finland, Germany, Iceland, Ireland, Italy, Japan, Netherlands, New Zealand, Norway, Sweden, Switzerland, United Kingdom, and United States (World Bank (2002) classification).

IMF pegged exchange rate countries: Argentina, Austria, Barbados, Burkina Faso, Cameroon, Central African Republic, Chad, Republic of Congo, Côte d'Ivoire, Dominican Republic, Egypt, El Salvador, Ethiopia, Fiji, Finland, Gabon, Guatemala, Guyana, Haiti, Honduras, Hungary, Islamic Republic of Iran, Kenya, Lesotho, Malawi, Malaysia, Malta, Mauritania, Mauritius, Morocco, Myanmar, Niger, Norway, Panama, Papua New Guinea, Paraguay, Rwanda, Samoa, Senegal, Seychelles, Sudan, Sweden, Syria, Tanzania, Thailand, Togo, Trinidad and Tobago, República Bolivariana de Venezuela, and Zambia (AREAER classification; see Appendix I).

IMF intermediate exchange rate countries: Belgium, Germany, Ireland, Italy, Nepal, and Netherlands (AREAER classification; see Appendix I).

IMF flexible exchange rate countries: Australia, Bolivia, Brazil, Canada, Chile, Colombia, Democratic Republic of the Congo, Costa Rica, Ecuador, The Gambia, Ghana, Iceland, India, Indonesia, Jamaica, Japan, Korea, Madagascar, Mexico, New Zealand, Nigeria, Pakistan, Peru, Philippines, Portugal, Sierra Leone, Spain, Sri Lanka, Switzerland, Tunisia, Turkey, Uganda, United Kingdom, United States, and Uruguay (AREAER classification; see Appendix I).

Reinhart and Rogoff pegged exchange rate countries: Austria, Belgium, Burkina Faso, Cameroon, Central African Republic, Chad, Côte d'Ivoire, Ecuador, El Salvador, Gabon, Guatemala, Haiti, Kenya, Lesotho, Mexico, Netherlands, Niger, Panama, Senegal, Thailand, Togo, and República Bolivariana de Venezuela (Reinhart and Rogoff (2002) classification; see Appendix I).

Reinhart and Rogoff limited flexibility and managed float exchange rate countries: Bolivia, Canada, Chile, Colombia, Costa Rica, Dominican Republic, Egypt, Finland, The 
Gambia, Guyana, Honduras, Hungary, Iceland, India, Indonesia, Islamic Republic of Iran, Ireland, Italy, Jamaica, Korea, Madagascar, Malawi, Malaysia, Malta, Mauritania, Mauritius, Morocco, Myanmar, Nepal, New Zealand, Nigeria, Norway, Pakistan, Paraguay, Philippines, Portugal, Spain, Sri Lanka, Sweden, Switzerland, Syria, Tanzania, Tunisia, Uganda, and United Kingdom (Reinhart and Rogoff (2002) classification; see Appendix I).

Reinhart and Rogoff freely floating/falling exchange rate countries: Argentina, Australia, Brazil, Republic of Congo, Germany, Ghana, Japan, Peru, Turkey, United States, Uruguay, and Zambia (Reinhart and Rogoff (2002) classification; see Appendix I).

\section{REFERENCES}

Andrews, David, Anthony Boote, Syed Rizavi, and Sukwinder Singh, 1999, Debt Relief for Low-Income Countries: The Enhanced HIPC Initiative, IMF Pamphlet Series, No. 51 (Washington: International Monetary Fund).

Andrews, Donald, 1993, "Exactly Median-Unbiased Estimation of First Order Autoregressive/ Unit Root Models," Econometrica, Vol. 61 (1), pp. 139-66.

_ and Hong-Yuan Chen, 1994, "Approximately Median-Unbiased Estimation of Autoregressive Models," Journal of Business and Economic Statistics, Vol. 12 (April), pp. 187-204.

Bahmani-Oskooee, M., 1995, "Real and Nominal Effective Exchange Rates for 22 LDCs: 1971:1-1990:4," Applied Economics, Vol. 27 (July), pp. 591-604.

Balassa, Bela, 1964, "The Purchasing Power Parity Doctrine: A Reappraisal," Journal of Political Economy, Vol. 72, pp. 584-96.

Bergin, Paul, and Robert Feenstra, 2001, "Pricing-to-Market, Staggered Contracts, and Real Exchange Rate Persistence," Journal of International Economics, Vol. 54 (August), pp. 333-59.

Bubula, Andrea, and Inci Otker-Robe, 2002, “The Evolution of Exchange Rate Regimes Since 1990: Evidence from De Facto Policies," IMF Working Paper 02/155 (Washington: International Monetary Fund).

Calvo, Guillermo, Carmen Reinhart, and Carlos Végh, 1995, "Targeting the Real Exchange Rate: Theory and Evidence," Journal of Development Economics, Vol. 47 (June), pp. 97-133.

Cashin, Paul, Luis Céspedes, and Ratna Sahay, 2004, "Commodity Currencies and the Real Exchange Rate," Journal of Development Economics, Vol. 75 (October), pp. 239-68.

Cashin, Paul, Hong Liang, and C. John McDermott, 2000, "How Persistent Are Shocks to World Commodity Prices?” IMF Staff Papers, Vol. 47 (December), pp. 177-217.

Cashin, Paul, and C. John McDermott, 2003, "An Unbiased Appraisal of Purchasing Power Parity," IMF Staff Papers, Vol. 50 (September), pp. 321-51.

— or Long-Lived?” Journal of Development Economics, Vol. 73 (April), pp. 727-44.

Chen, Shiu-Sheng, and Charles Engel, 2004, "Does 'Aggregation Bias' Explain the PPP Puzzle?" NBER Working Paper No. 10304 (Cambridge, Massachusetts: National Bureau of Economic Research).

Chen, Yu-Chin, and Kenneth Rogoff, 2003, "Commodity Currencies," Journal of International Economics, Vol. 60 (May), pp. 133-60.

Cheung, Yin-Wong, Menzie Chinn, and Eiji Fujii, 2001, "Market Structure and the Persistence of Sectoral Real Exchange Rates," International Journal of Finance and Economics, Vol. 6 (April), pp. 95-114. 
Cheung, Yin-Wong, and Kon S. Lai, 2000a, "On Cross-Country Differences in the Persistence of Real Exchange Rates," Journal of International Economics, Vol. 50 (April), pp. 375-97.

_ 2000b, "On the Purchasing Power Parity Puzzle," Journal of International Economics, Vol. 52 (December), pp. 321-30.

Conover, W. J., 1999, Practical Nonparametric Statistics (New York: Wiley, 3rd ed.).

Devereux, J., and M. Connolly, 1996, "Commercial Policy, the Terms of Trade and the Real Exchange Rate Revisited," Journal of Development Economics, Vol. 50 (June), pp. 81-99.

Edwards, Sebastian, and Miguel A. Savastano, 2000, "Exchange Rates in Emerging Economies: What Do We Know? What Do We Need to Know?" in Economic Policy Reform: The Second Stage, ed. by Anne O. Krueger (Chicago: University of Chicago Press), pp. 453-510.

Faruqee, Hamid, 1995, "Pricing to Market and the Real Exchange Rate," IMF Staff Papers, Vol. 42, No. 4, pp. 855-81.

Frenkel, Jacob, 1978, "Purchasing Power Parity: Doctrinal Perspective and Evidence from the 1920s," Journal of International Economics, Vol. 8 (May), pp. 169-91.

Froot, Kenneth, and Kenneth Rogoff, 1991, "The EMS, the EMU, and the Transition to a Common Currency," in NBER Macroeconomics Annual 1991, ed. by Olivier Blanchard and Stanley Fischer (Cambridge, Massachusetts: MIT Press), pp. 269-317.

_ 1995, "Perspectives on PPP and the Long-Run Real Exchange Rates," in Handbook of International Economics, Vol. 3, ed. by Gene Grossman and Kenneth Rogoff (Amsterdam: Elsevier), pp. 1647-88.

Goldfajn, Ilan, and Rodrigo Valdés, 1999, “The Aftermath of Appreciations," Quarterly Journal of Economics, Vol. 114 (February), pp. 229-62.

Imbs, Jean, Haroon Mumtaz, Morten Ravn, and Hélène Rey, 2005, "PPP Strikes Back: Aggregation and the Real Exchange Rate," Quarterly Journal of Economics, Vol. 120 (February), pp. 1-43.

International Monetary Fund, 1998, Annual Report on Exchange Arrangements and Exchange Restrictions, and earlier issues (Washington).

— 2000, World Economic Outlook: May 2000 (Washington).

—, 2002, World Economic Outlook: September 2002 (Washington).

McDermott, C. John, 1996, "Estimation of the Near Unit Root Model of Real Exchange Rates," IMF Working Paper 96/50 (Washington: International Monetary Fund).

McNown, R., and M. Wallace, 1989, "National Price Levels, Purchasing Power Parity, and Cointegration: A Test of Four High-Inflation Economies," Journal of International Money and Finance, Vol. 8 (December), pp. 533-45.

Montiel, Peter, 1997, "Exchange Rate Policy and Macroeconomic Management in ASEAN Countries," in Macroeconomic Issues Facing ASEAN Countries, ed. by J. Hicklin, D. Robinson, and A. Singh (Washington: International Monetary Fund), pp. 253-98.

Murray, Christian, and David Papell, 2002, "The Purchasing Power Parity Persistence Paradigm," Journal of International Economics, Vol. 56 (January), pp. 1-19.

Mussa, Michael, 1986, "Nominal Exchange Rate Regimes and the Behavior of Real Exchange Rates: Evidence and Implications," Carnegie-Rochester Conference Series on Public Policy, Vol. 25, pp. 117-213.

Reinhart, Carmen, and Kenneth Rogoff, 2002, "The Modern History of Exchange Rate Arrangements: A Reinterpretation," NBER Working Paper No. 8963 (Cambridge, Massachusetts: National Bureau of Economic Research).

Rogoff, Kenneth, 1996, “The Purchasing Power Parity Puzzle," Journal of Economic Literature, Vol. 34 (June), pp. 647-68. 
, Kenneth Froot, and Michael Kim, 2001, “The Law of One Price Over 700 Years," IMF Working Paper 01/174 (Washington: International Monetary Fund).

Romer, David, 1993, "Openness and Inflation: Theory and Evidence," Quarterly Journal of Economics, Vol. 108 (November), pp. 869-903.

Sarno, Lucio, and Mark P. Taylor, 2002, "Purchasing Power Parity and the Real Exchange Rate," IMF Staff Papers, Vol. 49 (April), pp. 65-105.

Taylor, Alan, 2001, "Potential Pitfalls for the Purchasing-Power-Parity Puzzle? Sampling and Specification Biases in Mean-Reversion Tests of the Law of One Price," Econometrica, Vol. 69 (2), pp. 473-98.

Taylor, Mark P., 2003, "Purchasing Power Parity," Review of International Economics, Vol. 11 (August), pp. 436-452.

_, and Lucio Sarno, 1998, "The Behavior of Real Exchange Rates During the PostBretton Woods Period," Journal of International Economics, Vol. 46 (December), pp. 281-312.

Wickham, Peter, 1993, "A Cautionary Note on the Use of Exchange Rate Indicators," IMF Paper on Policy Analysis and Assessment No. 93/5 (Washington: International Monetary Fund).

World Bank, 2002, World Development Indicators (Washington).

Zanello, Alessandro, and Dominique Desruelle, 1997, "A Primer on the IMF's Information Notice System," IMF Working Paper 97/71 (Washington: International Monetary Fund).

Zar, Jerrold, 1972, "Significance Testing of the Spearman Rank Correlation Coefficient," Journal of the American Statistical Association, Vol. 67 (September), pp. 578-80. 